Review Article

\title{
Ribonuclease $\mathrm{H}$, an unexploited target for antiviral intervention against $\mathrm{HIV}$ and hepatitis $B$ virus
}

\author{
Enzo Tramontano ${ }^{\mathrm{a}, * *}$, Angela Corona ${ }^{\mathrm{a}}$, Luis Menéndez-Arias, ${ }^{\mathrm{b}, *}$

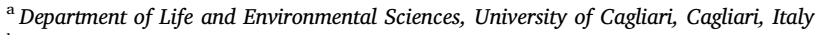 \\ b Centro de Biología Molecular "Severo Ochoa" (Consejo Superior de Investigaciones Científicas \& Universidad Autónoma de Madrid), Madrid, Spain
}

\section{A R T I C L E I N F O}

\section{Keywords:}

Ribonuclease $\mathrm{H}$

Reverse transcriptase

HIV

Hepatitis B virus

Antiviral

\begin{abstract}
A B S T R A C T
Ribonucleases H (RNases $\mathrm{H}$ ) are endonucleolytic enzymes, evolutionarily related to retroviral integrases, DNA transposases, resolvases and numerous nucleases. RNases H cleave RNA in RNA/DNA hybrids and their activity plays an important role in the replication of prokaryotic and eukaryotic genomes, as well as in the replication of reverse-transcribing viruses. During reverse transcription, the RNase $\mathrm{H}$ activity of human immunodeficiency virus (HIV) and hepatitis B virus (HBV) degrades the viral genomic RNA to facilitate the synthesis of viral double-stranded DNA. HIV and HBV reverse transcriptases contain DNA polymerase and RNase $\mathrm{H}$ domains that act in a coordinated manner to produce double-stranded viral DNA. Although RNase H inhibitors have not been developed into licensed drugs, recent progress has led to the identification of a number of small molecules with inhibitory activity at low micromolar or even nanomolar concentrations. These compounds can be classified into metal-chelating active site inhibitors and allosteric inhibitors. Among them, $\alpha$-hydroxytropolones, N-hydroxyisoquinolinediones and N-hydroxypyridinediones represent chemotypes active against both HIV and HBV RNases H. In this review we summarize recent developments in the field including the identification of novel RNase H inhibitors, compounds with dual inhibitory activity, broad specificity and efforts to decrease their toxicity.
\end{abstract}

\section{Introduction}

Reverse-transcribing viruses include important human pathogens, such as the human immunodeficiency viruses type 1 and type 2 (HIV-1 and HIV-2, respectively) and the hepatitis B virus (Menéndez-Arias et al., 2017). HIV is the etiological agent of the acquired immunodeficiency syndrome (AIDS). The number of people living with HIV worldwide is very high with current estimates ranging between 32.7 and 44 million people (average 37.9 million in 2018). Although the number of new infections has been steadily declining since the mid90s, UNAIDS estimates that 1.7 million people got infected in 2018, while the disease was globally responsible for around 770,000 deaths (www.unaids.org). At present, no vaccine or cure is available, although highly active antiretroviral therapy (HAART) has been highly effective in controlling viral load and preventing the onset of symptoms and progression to AIDS.

Most of the currently approved anti-HIV drugs are inhibitors of enzymes encoded within the viral genome: (i) DNA polymerase activity of HIV reverse transcriptase (RT), (ii) strand transfer activity of HIV integrase (IN), and (iii) the proteolytic activity of HIV protease (Menéndez-Arias, 2013). These drugs block viral replication, integration and maturation, respectively. In addition, drugs targeting viral entry (e.g. coreceptor antagonists or fusion inhibitors) are used in salvage therapies. Despite the success of antiretroviral therapy, acquired and transmitted drug resistance as well as long-term toxicity pose a major limitation to the long-term efficacy of current therapies, and research towards exploiting other targets of antiviral intervention is still important for preparedness against future outcomes of the disease.

Hepatitis B virus (HBV) infection remains an important cause of morbidity and mortality. According to current estimates, there are more than 250 million people chronically infected with the virus (MacLachlan and Cowie, 2015; Seto et al., 2018) and twenty to thirty percent of the chronically infected adults develop cirrhosis and liver cancer (Seto et al., 2018). HBV and associated liver diseases are responsible for nearly 900,000 deaths each year, mostly from complications (including cirrhosis and hepatocellular carcinoma) (WHO, 2017). Infection and development of chronic disease can be prevented by HBV vaccination, which is most effective if given within $24 \mathrm{~h}$ after birth

\footnotetext{
* Corresponding author.

** Corresponding author.

E-mail addresses: tramon@unica.it (E. Tramontano), lmenendez@cbm.csic.es (L. Menéndez-Arias).
} 
(followed by two to three doses at monthly intervals). However, timely infant vaccination has not been implemented everywhere and despite progress, universal coverage is very difficult to achieve (Chang and Nguyen, 2017). On the other hand, available treatments (long-term nucleos(t)ide-analogue therapies) are safe and well tolerated, achieve potent viral suppression, and reduce the incidence of liver-related complications (Menéndez-Arias et al., 2014; Levrero et al., 2018). However, approved treatments act exclusively on viral replication by inhibiting DNA synthesis catalyzed by the HBV polymerase, and current research focuses on alternative targets for the development of anti-HBV drugs (Pei et al., 2017).

Approximately $10 \%$ of the HIV-infected population worldwide is coinfected with HBV, although this figure can be higher in several regions of Southeast Asia (Singh et al., 2017). HIV reverse transcriptase and HBV polymerase inhibitors constitute the backbone of antiviral therapies against both pathogens. These drugs block viral DNA synthesis during reverse transcription, although an obligatory step in the process involves the degradation of viral RNA by the associated ribonuclease $\mathrm{H}$ (RNase $\mathrm{H}$ ) activity of the HIV and HBV polymerases. To date, RNase $\mathrm{H}$ remains as an unexploited target in antiviral intervention, and despite efforts to identify specific inhibitors, none of those compounds has been approved for clinical use. In this review, we will summarize current knowledge on the structure and catalytic mechanism of RNases $\mathrm{H}$, and efforts to discover and develop compounds targeting the RNase $\mathrm{H}$ activity of HIV and HBV.

\section{RNase $H$ and reverse transcription}

RNases $\mathrm{H}$ constitute a family of non-sequence-specific endonuclease enzymes that catalyze the cleavage of RNA in RNA/DNA substrates through a hydrolytic mechanism. Members of the RNase $\mathrm{H}$ family can be found in nearly all organisms, from bacteria to archaea to eukaryotes (Majorek et al., 2014; Moelling et al., 2017). These enzymes are involved in many processes such as transposition, replication and repair of DNA, homologous recombination and RNA-mediated gene silencing.

Soon after the discovery of retroviral RTs, its associated RNase $\mathrm{H}$ activity was identified as an essential component of the enzyme (Mölling et al., 1971). Retroviral RTs contain DNA polymerase and RNase $\mathrm{H}$ activities that during reverse transcription act in a concerted manner to generate double-stranded DNA from the viral genomic RNA. RNase H cleaves the RNA strand of RNA/DNA hybrids created when the RT polymerase activity synthesizes DNA using the viral RNA as template. In addition, the RT's RNase $\mathrm{H}$ activity degrades the primer tRNA during plus-strand DNA synthesis, and facilitates the generation of polypurine tracts (PPTs) needed for plus-strand DNA synthesis (reviewed in Menéndez-Arias et al., 2017). RNases H are present in all viral families included in the order Ortervirales (Retroviridae, Metaviridae, Pseudoviridae, Belpaoviridae and Caulimoviridae) (Krupovic et al., 2018), as well as in hepadnaviruses (Hepadnaviridae). In all cases, the RNase $\mathrm{H}$ domain of the viral polymerase is encoded at the $3^{\prime}$ of the DNA polymerase domain (Menéndez-Arias et al., 2017; Krupovic et al., 2018).

HIV-1 reverse transcription is outlined in Fig. 1. The process involves a series of steps catalyzed by the viral RT by which the HIV genomic RNA is converted into double-stranded DNA (provirus) that is then integrated in the host cell's genome (for recent reviews, see Hughes, 2015; Menéndez-Arias et al., 2017). RT possesses RNA- and DNA-dependent DNA polymerase and RNase $\mathrm{H}$ activities, both required to complete reverse transcription. First, a cellular transfer RNA (tRNA) is used as primer to synthesize the minus $(-)$ strand DNA, while the RNase $\mathrm{H}$ activity of the RT degrades the template RNA. After a first strand transfer event, DNA synthesis continues while the RNA is almost completely degraded leaving uncleaved the polypurine tracts (PPTs). These PPTs are used as primers to initiate plus (+)-strand DNA synthesis. After removal of the PPTs by the RT's RNase H activity, an additional transfer event facilitates completion of the proviral DNA synthesis with the removal of the tRNA primer, also catalyzed by the RNase H.

Reverse transcription shows remarkable differences in HBV compared to HIV and other retroviruses (Fig. 1) (Hu and Seeger, 2015; Menéndez-Arias et al., 2017). However, in both viruses the RNase $H$ activity of the viral polymerase plays a prominent role. In HBV reverse transcription, the pregenomic RNA (pgRNA) is extensively degraded during minus-strand DNA synthesis, although the last cleavage occurs away from the capped 5' end, leaving an RNA sequence (direct repeat 1 , or DR1) that is used as primer for plus-strand DNA synthesis (Nassal, 2008; Hu and Seeger, 2015). The RNA primer can also translocate to the DR2 region at the 5' end of the minus-strand DNA, thereby facilitating the circularization of the DNA genome after the corresponding template switch (rcDNA formation). The conversion of rcDNA into covalently closed circular DNA (cccDNA) involves a series of biochemical events including the removal of the 18-nt long RNA primer used in plusstranded DNA synthesis, but the molecular mechanisms have not been elucidated and the participation of the viral RNase $\mathrm{H}$ is not clear yet (Hu and Seeger, 2015; Menéndez-Arias et al., 2017).

\section{RNase $\mathbf{H}$ function and structure}

RNases $\mathrm{H}$ are among the most abundant proteins on our planet. RNases $\mathrm{H}$ bind to RNA/DNA hybrids in a sequence-nonspecific manner and degrade the RNA strand. Eukaryotic RNase $\mathrm{H}$ was initially discovered in calf thymus lysates, although its role was unknown for a long time (Stein and Hausen, 1969). Its involvement in DNA replication was later suggested after being found in Saccharomyces cerevisiae (Karwan and Wintersberger, 1986).

According to their structural features and evolutionary relationships, RNases $\mathrm{H}$ have been classified into two major groups (RNase H1 or $\mathrm{HI}$ and RNase $\mathrm{H} 2$ or $\mathrm{HII}$ ). Arabic numerals have been traditionally used to designate eukaryotic RNases $\mathrm{H}$ ( $\mathrm{H} 1$ and $\mathrm{H} 2$ ), while Roman numbers were assigned to prokaryotic enzymes (RNase HI and HII). Type 1 RNases $\mathrm{H}$ are found in eukaryotic, bacterial and viral proteins, including those associated with RTs (e.g. HIV RT and HBV polymerase). Type 2 RNases are also found in eukaryotes, as well as in prokaryotes, including archaea. A third related class (designated RNase HIII) and related to prokaryotic RNase HII has also been found in a few bacteria and archaea (Figiel and Nowotny, 2014).

H1 and H2 enzymes are necessary to maintain genome stability (Amon and Koshland, 2016; Lima et al., 2016). However, none of them is essential for removal of RNA primers that initiate lagging strand DNA synthesis (i.e. Okazaki fragments) during DNA replication as initially suggested by Kogoma and Foster (1998). However, RNase H1 null mice die during embryonic development because the enzyme plays a critical role in mitochondrial DNA replication (Cerritelli et al., 2003). In addition, RNases $\mathrm{H}$ are important to maintain the cellular dNTP/rNTP concentration ratio depending on the cell cycle stage, the tissue or the organisms; and this way, preventing the incorporation into DNA of the more abundant rNTPs as occurs in many cell types (e.g. human macrophages, human PBMCs, yeast cells, etc.).

Structural studies have shown that RNases $\mathrm{H}$ have a characteristic fold (Katayanagi et al., 1990; Yang et al., 1990) shared by numerous enzymes involved in nucleic acid metabolism, and clearly distinguished from that observed in most exonucleases and endonucleases (Rice and Baker, 2001). The basic fold is constituted by a five stranded $\beta$-sheet (strands ordered as 3-2-1-4-5) where $\beta$-strand 2 runs antiparallel to the others, and $\beta$-strands 1,2 and 3 are longer than strands 4 and 5 (Fig. 2). In addition to the central $\beta$-sheet, the folds contain $\alpha$-helices at different positions and arrangement (Nowotny, 2009; Majorek et al., 2014; Hyjek et al., 2019). This fold has been found in many other proteins integrated in a large RNase H-like superfamily. Examples are transposases (e.g. bacteriophage MuA, E. coli Tn5, and Hermes transposase from Musca domestica), retroviral INs (e.g. HIV-1 IN catalytic domain), DDE endonucleases (e.g. E. coli RuvC endodeoxyribonuclease, mitochondrial 
A

genomic RNA
(ssRNA) $5^{\prime}$ cap $\mathrm{R} \quad$ U5 PBS $g a g$ pol $\quad$ env $\quad$ PPT U3 $R$ AAAA 3'

minus (-) strand

DNA synthesis
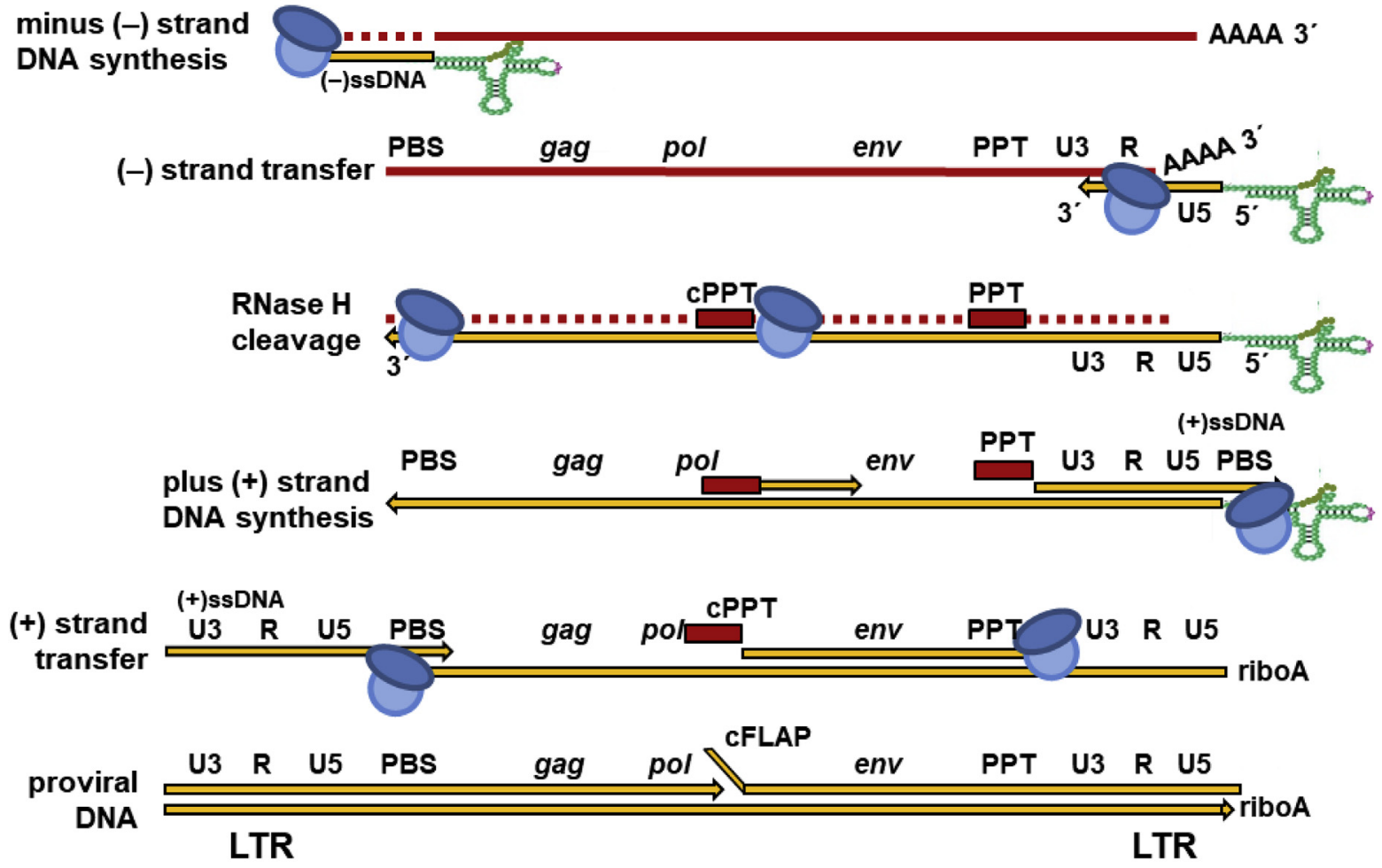

B

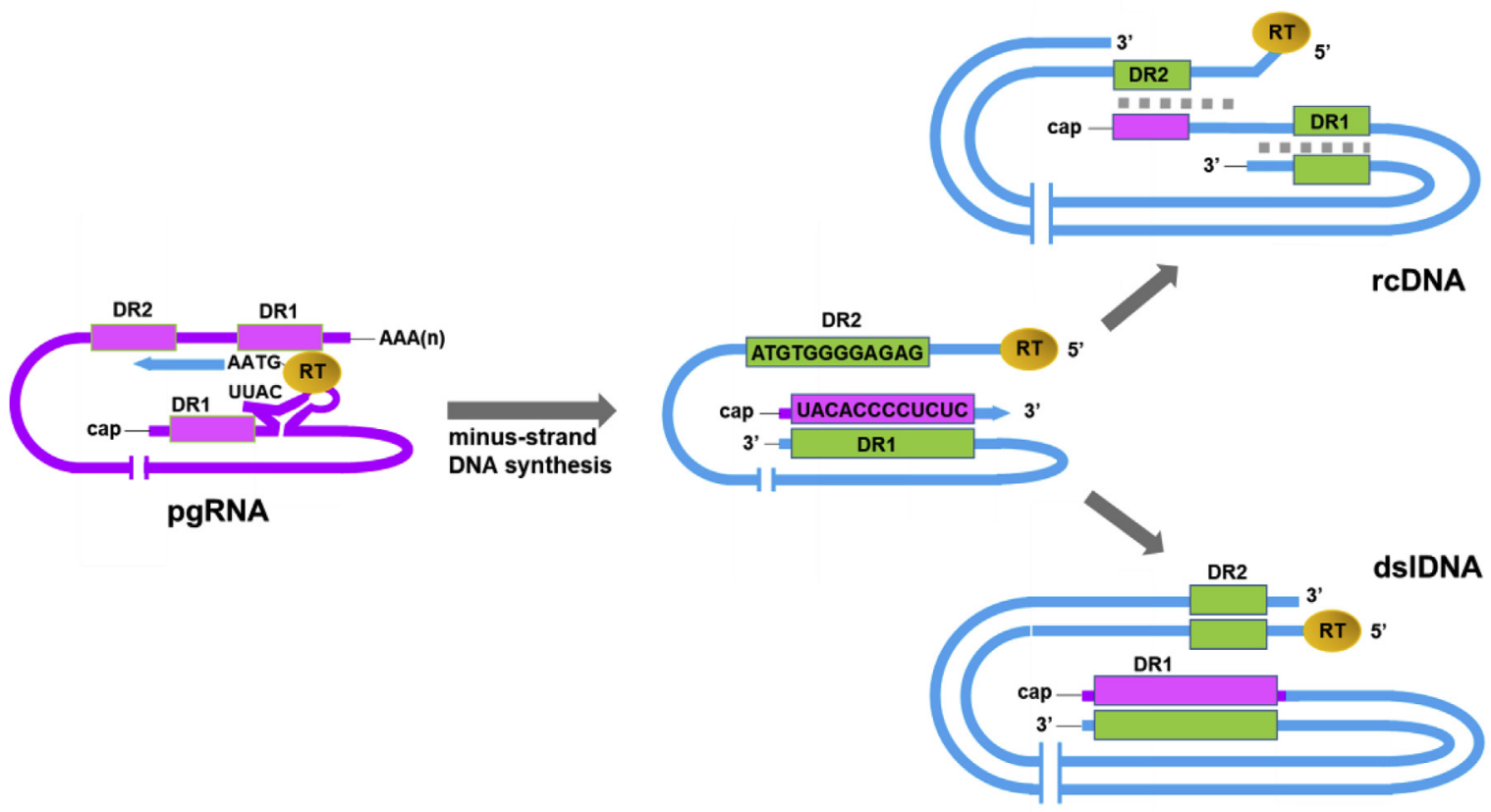

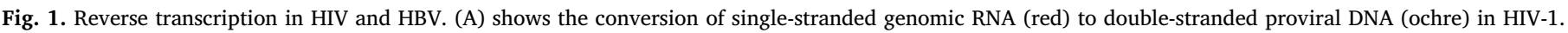

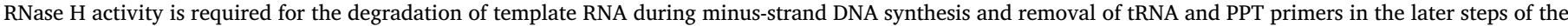

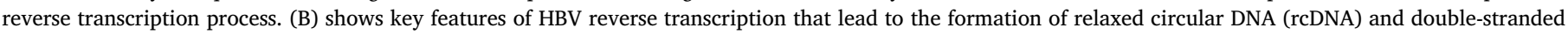

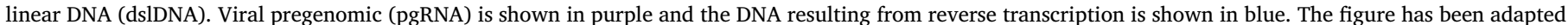
from Menéndez-Arias et al. (2017). 


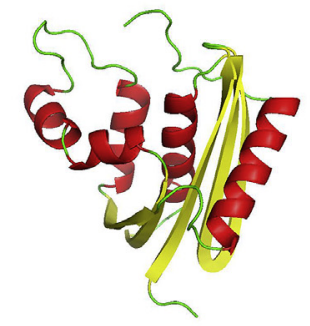

Escherichia coli RNase HI

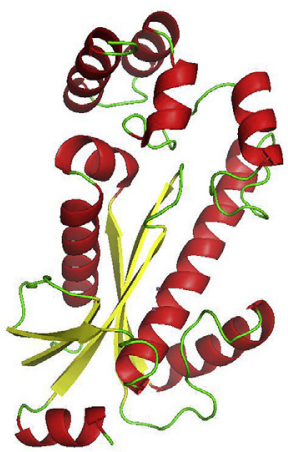

Thermotoga maritima RNase HII

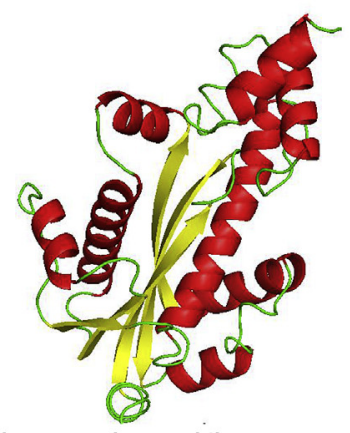

Bacillus stearothermophilus RNase HIII
Fig. 2. Structures of prokaryotic RNases HI, HII and HIII. The RNase $\mathrm{H}$ fold is shown in yellow and $\alpha$ helices are depicted in red. Crystal structures have been obtained from Protein Data Bank files 2RN2 (E. coli RNase $\mathrm{HI}$ ), 3O3F (Thermotoga maritima RNase HII) and 2D0B (Bacillus stearothermophilus RNase HIII). Images have been prepared using the program PyMOL (www.pymol.org). resolvase Ydc2, poxvirus A22 protein, Piwi/Argonaute domain sequences, the UvrC excinuclease and phage terminases), and other enzymes related to $3^{\prime}-5^{\prime}$ exonucleases found in eukaryotic and prokaryotic DNA polymerases (Majorek et al., 2014).

Crystal structures of representative prokaryotic RNases $\mathrm{H}$ of each type (HI, HII and HIII) are available (Fig. 2). All of them are monomeric enzymes. However, they show remarkable differences in domain structures and substrate specificities. For example, RNases HIII have long N-terminal extensions absent in RNases HI and HII (Chon et al., 2006). The amino acid sequences of those extensions are similar to those of TATA-box binding proteins (TBPs) and contribute to the substrate-binding domain of the enzyme. In contrast, E. coli RNase HI and Thermococcus kodakaraensis RNase HII have a substrate-binding domain that extends through the central and C-terminal regions of the molecule (for a review, see Tadokoro and Kanaya, 2009). The structural diversity found in prokaryotic RNases $\mathrm{H}$ is observed even within the same type. Thus, E. coli RNase HI has a protruding basic domain (Katayanagi et al., 1990; Yang et al., 1990), absent in other HI enzymes, such as the one found in the archaeon Sulfolobus tokodaii (You et al., 2007).

Human RNase $\mathrm{H} 1$ and RNase $\mathrm{H}$ domains of retroviral RTs are homologs of $E$. coli RNase HI (Fig. 3). Their structural relationship to HBV RNase $\mathrm{H}$ is also assumed although structural data are still missing. In humans, as well as in other eukaryotic organisms, there are two types of RNase $\mathrm{H}$ ( $\mathrm{H} 1$ and $\mathrm{H} 2$ ). RNase $\mathrm{H} 1$ is a monomeric enzyme of $32 \mathrm{kDa}$ (Wu et al., 1998), containing an RNase H domain (spanning residues 136-282) similar to that shown by the E. coli RNase HI (Nowotny et al., 2007), while RNase H2 is composed of three different subunits (Jeong et al., 2004; Figiel et al., 2011) (Fig. 3). The human genome contains four RNase H genes: RNASEH1 (encoding for the monomeric RNase $\mathrm{H} 1$ ), and RNASEH2A, RNASEH2B and RNASEH2C that encode the
RNase H2 catalytic subunit A and structural subunits B and C, respectively.

\section{Catalytic sites and mechanism of action}

RNases $\mathrm{H}$ cleave the phosphodiester bonds of RNA in RNA/DNA hybrids, leaving a $3^{\prime} \mathrm{OH}$ and a $5^{\prime}$ phosphate group on either end of the cleavage site. RNases $\mathrm{H} 1$ and $\mathrm{H} 2$ have different substrate specificities. While RNases $\mathrm{H} 2$ cleave preferentially at the 5' end of RNA in chimeric DNA-RNA-DNA/DNA hybrids and hydrolyzes substrate even when it contains one ribonucleotide, cleavage by human RNase $\mathrm{H} 1$ requires a nucleotide sequence containing at least four rNTPs (Ohtani et al., 1999).

The active site of most RNases $\mathrm{H}$ contains four negatively charged amino acid residues, known as the DEDD motif. In some enzymes, an additional His residue is present and contributes to their catalytic efficiency. The conserved negatively charged residues bind either one or two metal ions that are required for catalysis. Under physiological conditions, the preferred cation is $\mathrm{Mg}^{2+}$, although $\mathrm{Mn}^{2+}$ also supports catalysis, while $\mathrm{Ca}^{2+}$ inhibits cleavage (Nowotny and Yang, 2006; Rosta et al., 2014). Reactions occur through the formation of a pentavalent intermediate and inversion of the phosphate stereo configuration (Steitz and Steitz, 1993; Yang et al., 2006).

Although a classical two-metal-ion catalytic mechanism has been proposed for RNase $\mathrm{H}$, the question of whether one or two ions are used in RNase $\mathrm{H}$ catalysis has been a controversial issue in the field (Klumpp et al., 2003; Yang et al., 2006). A view of the catalytic site of a type 1 RNase H is shown on Fig. 4. Deprotonation of a water molecule generates a nucleophile hydroxide group that attacks the scissile phosphate on the RNA to complete the hydrolysis reaction. The side chains of

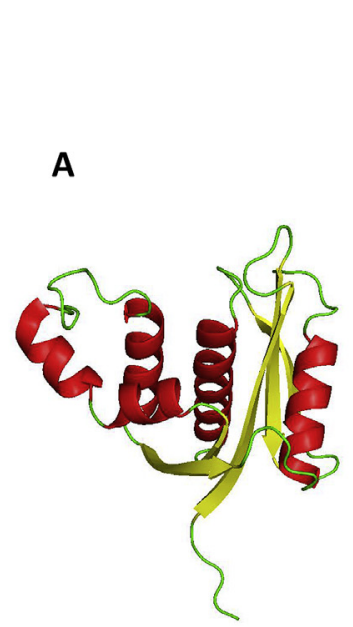

Human RNase H1

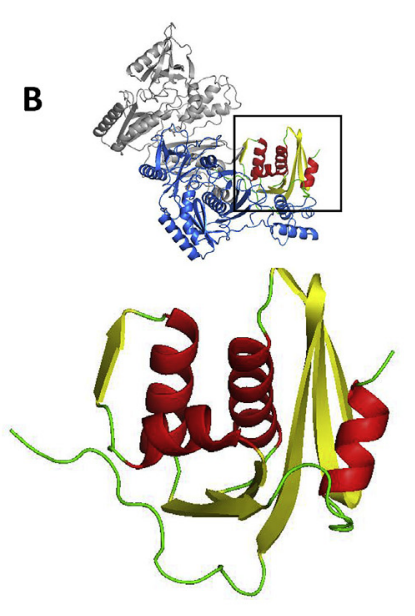

HIV-1 RT-RNase H domain

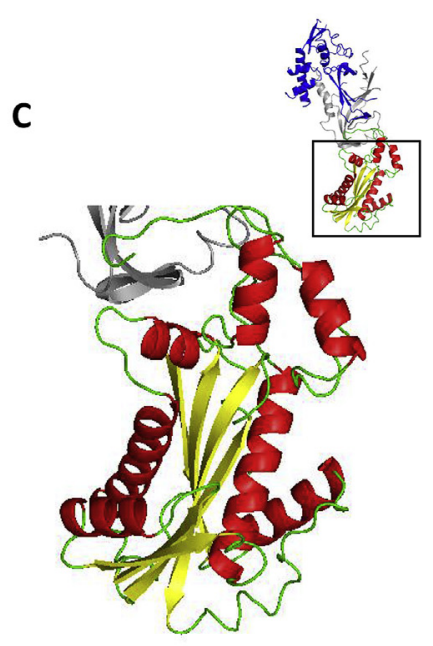

Human RNase $\mathrm{H} 2$

Fig. 3. Structures of human RNases $\mathrm{H} 1$ and $\mathrm{H} 2$ and comparison with the RNase H domain of HIV-1 RT. The $\beta$-sheet structures (including the RNase $\mathrm{H}$ fold) are shown in yellow, $\alpha$-helices in red, and loops in green. In the HIV-1 RNase $\mathrm{H}$ structure, blue cartoons represent the connection and DNA polymerase domains of the RT. Human RNase H2 has three subunits: the catalytic subunit A (with the RNase $\mathrm{H}$ fold), and subunits B (in grey) and C (in light blue). Crystal structures have been obtained from Protein Data Bank files 2QK9 (human RNase H1), 1RTD (HIV-1 RT) and 3PUF (human RNase H2). Images have been prepared using PyMOL (www.pymol.org). 


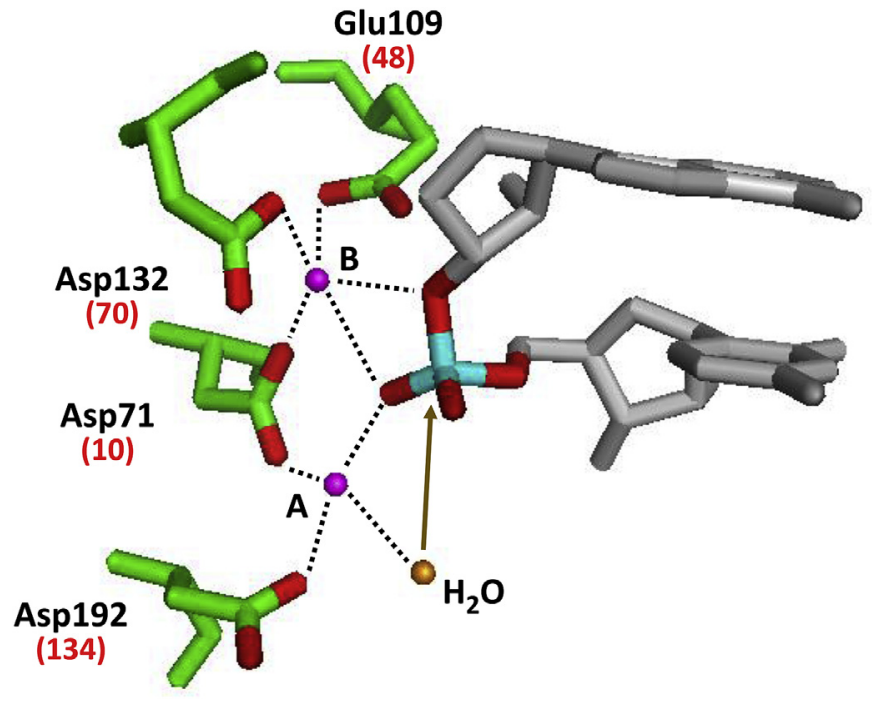

Fig. 4. Catalytic site of a type 1 RNase H. Side-chains of conserved catalytic residues forming the DEDD motif are shown together with the two metal ions and the scissile bond in the RNA substrate. Ionic and hydrogen bonds interactions between the active site residues and the magnesium cations are shown. The diagram was prepared with PyMOL using the Protein Data Bank coordinates 1ZBL corresponding to the Bacillus halodurans RNase HI. Amino acid residue numbering corresponds to the $B$. halodurans enzyme, but red numbers between parentheses are those of the closely related RNase HI of E. coli.

residues forming the DEDD motif and a hydroxyl substituent in the RNA substrate coordinate the two divalent cations required as cofactors for catalysis.

\section{Retroviral RT-associated RNases H}

The RNase H domains of HIV-1 and murine leukemia virus (MLV) RTs show a very similar tertiary folding, although the HIV-1 RNase $\mathrm{H}$ domain lacks a positively charged $\alpha$-helix (known as helix C) containing the amino acid sequence HGEIYRRR of MLV RT (reviewed in Coté and Roth, 2008). Crystal structures of HIV-1 and xenotropic murine leukemia virus-related virus (XMRV) RTs bound to double-stranded DNA have shown that the DNA polymerase and RNase $\mathrm{H}$ active sites are 14-18 nucleotides apart from each other (Huang et al., 1998; Nowak et al., 2013). The active sites of MLV and HIV-1 RNases H contain the four characteristic acidic residues forming the DEDD cluster found in most RNases H. Thus, Asp443, Glu478, Asp498 and Asp549 in HIV-1 RT are equivalent to Asp10, Glu48, Asp70 and Asp134 in E. coli RNase HI, and residues Asp145, Glu186, Asp210 and Asp274 of human RNase H1 (Fig. 5).

Unlike the homologous prokaryotic and eukaryotic type 1 RNases $\mathrm{H}$, RNA/DNA substrates can interact with the RT in different modes, rendering different cleavage patterns. RNA cleavage observed during DNA polymerization is determined by the positioning of the $3^{\prime}$ end of the DNA at the polymerase active site, in a "polymerase-dependent" mode. Alternatively, in the polymerase-independent mode, the DNA polymerase active site binds preferentially at a $5^{\prime}$ end of a recessed RNA annealed to a DNA strand, promoting cleavage of the RNA strand 13-19 nucleotides away from the RNA 5' end (DeStefano et al., 1991). In general, polymerase-independent cleavages render shorter products than polymerase-dependent hydrolysis, but with a larger size heterogeneity probably due to a stronger tendency of the enzyme to slide after the initial binding event. In addition, polymerase-independent cleavages can also generate the PPT primer and remove the extended tRNA and PPT primers to complete reverse transcription (reviewed in Schultz and Champoux, 2008). Studies carried out with HIV-1 RT have shown that RNase $\mathrm{H}$ cleavage proceeds at a 5 to 10 times slower rate than nucleotide incorporation (DeStefano et al., 1991; Kati et al., 1992; Li et al., 2016).

RNase $\mathrm{H}$ activity and specificity need to be finely coordinated with DNA polymerization since excessive degradation of the template RNA could lead to DNA synthesis termination due to early dissociation of the primer from the template strand. On the other hand, reduced RNase $\mathrm{H}$ activity might result in delays in plus-strand DNA synthesis and interfere with specific cleavages leading to PPT generation (Betancor et al., 2015). The relative contributions of internal and polymerase-dependent and -independent RNase $\mathrm{H}$ cleavages are not known, but they could have some relevance in the design of appropriate assays for screening candidate RNase H inhibitors (Boyer et al., 2018).

\section{HBV RNase $\mathrm{H}$}

The RNase H domain is located at the C-terminal region of the HBV polymerase, spanning residues 679 to 832 . It shows sequence homology with the HIV-1 RT RNase $\mathrm{H}$ domain as well as the E. coli RNase HI, although sequence identity is reduced to only $23 \%$ and $19 \%$ respectively, when considering the catalytic core domains of those enzymes (Schödel et al., 1988; Khudyakov and Makhov, 1989; Tavis et al., 2013) (Fig. 5). Mutagenesis studies carried out with duck and human HBV polymerase facilitated the identification of the RNase $\mathrm{H}$ catalytic acidic residues of the human HBV polymerase (Asp702, Glu731, Asp750 and Asp790) (Chang et al., 1990; Chen and Marion, 1996; Tavis et al., 2013). Eliminating RNase $\mathrm{H}$ activity by introducing non-conservative substitutions in the DEDD motif leads to accumulation of long RNA/ DNA heteroduplexes and truncation of minus-strand DNA, while plusstrand DNA is no longer produced, due to the suppression of the second and third strand transfer reactions. RNase H-inactivating mutations produce large reductions in the release of infectious virions and in the amounts of accumulated nuclear cccDNA.

Despite of its important role in viral replication, there are no structures available for the HBV polymerase or its RNase $\mathrm{H}$ domain, due in part to difficulties in obtaining sufficient quantities of active enzymes (Lanford et al., 1997; Jones et al., 2012; Vörös et al., 2014). Recombinant hexahistidine-tagged human HBV RNase $\mathrm{H}$ has been expressed and purified (Tavis et al., 2013) although yields were very low and hardly detectable in Western blots. Nevertheless, active RNase $\mathrm{H}$ could be obtained for four different HBV genotypes (i.e. B, C, D and H). The enzyme has been used in low-throughput drug screening efforts (Hu et al., 2013; Tavis et al., 2013; Cai et al., 2014; Lu et al., 2015), although its specific activity was very low. More recently, Villa et al. (2016) reported an extensive characterization of the HBV RNase H after successful expression and purification of the enzyme as a fusion protein with a maltose-binding domain at the $\mathrm{N}$-terminus and a hexahistidine tag at the C-terminal end. The enzyme was monomeric in the presence of $\mathrm{Mg}^{2+}$ and ATP, and required 14 nucleotides for efficient cleavage of RNA/DNA hybrids. Apart from its characteristic endonuclease activity, the HBV RNase $\mathrm{H}$ displayed $3^{\prime}-5^{\prime}$ exonuclease activity, although its catalytic rate was reduced in comparison with that observed for endonucleolytic cleavages.

\section{RNase $\mathbf{H}$ activity assays and inhibition}

Classical methods to determine RNase $\mathrm{H}$ activity monitor DNA oligonucleotide-directed RNA cleavage by using a ${ }^{32} \mathrm{P}$-labeled RNA template and a DNA primer (Evans et al., 1991). Hydrolysis products can be analyzed by phosphorimaging, and products can be quantified accurately using these methods. An interesting advantage of these methods is that allow the identification of different cleavage patterns and can be used to monitor sequence specificity with different RNA templates (Álvarez et al., 2009; Betancor et al., 2015). These methods can be easily adapted to assess RNase $\mathrm{H}$ inhibition in low-throughput screening campaigns and are still widely used in the search for HBV RNase H inhibitors (Lomonosova and Tavis, 2017). 


HBV RNase H
HIV RT RNase H
E. Coli RNase HI
Human RNase H1
HBV RNase H
HIV RT RNase H
E. coli RNase HI
Human RNase H1
HBV RNase H
HIV RT RNase H
E. CO Ti RNase HI
Human RNase H1

693 RPGLCQVFADATP-TGWGLVMGHQ-RMRG------TFSA------PLPIHTAELLAACFARSRSG 441 ------YVDGAANRETKL-GKAGYVTNRGRQ---KVVTL-----TDTTNQKTEL QAIYLALQDS1 136 MLKQVEIFTDGSCLGNPGPGGYGAILRYRGRE---KTFSAGYT---RTTNNRMELMAAIVALEALMGDFVVVYTDGCCSSNGRRRPRAGIGVYWGPG---HPLNVGIRLPGRQTNQRAEIHAACKAIEQAK $*$. $*$ .. $: *: * *$.

AN-----IIGTDNSVVLSRKYTSF---------------PWLLGCAANWILRGTSFVYVPS---GLEVNIVTDSQYALGIIQAQP------------DQSESELVNQIIEQLIKKEKVYLAWVPAH -KEHCEVILSTDSQYVRQGITQWIHNWKKRGWKTADKKPVKNVDLWQRLDAALGQHQIKWEWVKGH TQNINKLVLYTDSMFTINGITNWVQGWKKNGWKTSAGKEVINKEDFVALERLTQGMDIQWMHVPGH : **:

----ALNPADDPSRGRLGLSRPLLRLPFRPTTGRTSLYADSPSVPSHLPDRVHFASPLHVAWRPP

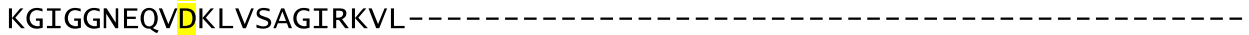

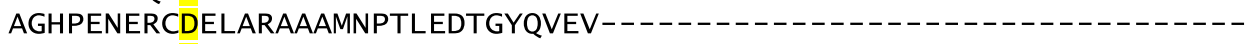

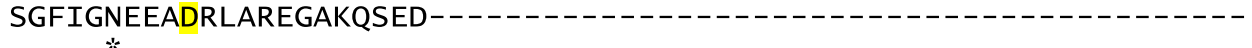

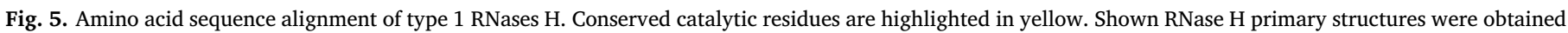

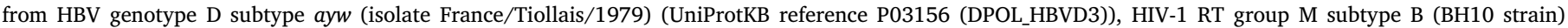

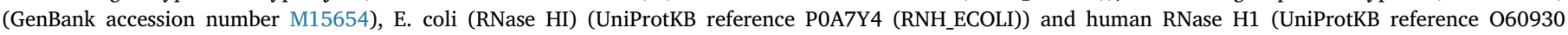
(RNH1_HUMAN)). Multiple sequence alignments were carried out online using CLUSTAL Omega (version 1.2.4).

The introduction of reliable assays using fluorescently labeled RNAs allowed high-throughput screening of RNase $\mathrm{H}$ inhibitors. The first assay of this kind was developed by Parniak et al. (2003). It used a 18nucleotide 3'-fluorescein-labeled RNA substrate annealed to a complementary 18-nucleotide 5'-Dabcyl-modified DNA. The intact duplex had an extremely low background fluorescent signal and provided a very versatile tool for the identification of inhibitors, because the reaction products could be quantified using a plate reader equipped with filters for fluorescein fluorophores (e.g. $490 \mathrm{~nm}$ and $528 \mathrm{~nm}$, for excitation and emission wavelengths, respectively). The protocol proved to generate results comparable and consistent with the ones obtained with the radiolabeled substrate, being sustainable and more environmental-friendly. Since then, the protocol has been widely used and adapted to screen for HIV-1 RNase $\mathrm{H}$ inhibitors on both low and high throughput techniques. Other methods based on the use of fluorophores such as FAM/BHQ1 (Li et al., 2012) or Cy3/Cy5 (Chung et al., 2013), or different types of molecular beacons (Chen et al., 2008; Liu et al., 2013) have also been described.

\section{HIV RNase $H$ inhibitors: design and development}

Success in the expression and purification of HIV-1 RT facilitated the screening of DNA polymerase and RNase $\mathrm{H}$ inhibitors. Illimaquinone, suramine and one cephalosporine degradation product were among the first compounds showing some selective inhibitory activity against HIV-1 RNase H (Loya et al., 1990; Hafkemeyer et al., 1991; Andréola et al., 1993). Illimaquinone was found to be active against retroviral RNases $\mathrm{H}$ of HIV-1, HIV-2 and MLV, as well as E. coli RNase HI (Loya and Hizi, 1993). N-(4-tert-butylbenzoyl)-2-hydroxy-1naphthaldehyde hydrazine (BBNH) was the first compound showing some relevant inhibitory effect against HIV-1 RT RNase H (Borkow et al., 1997) (Fig. 6). It showed an $\mathrm{IC}_{50}$ of $3.5 \mu \mathrm{M}$ in RNase H biochemical assays, although it was also an inhibitor of the RT DNA polymerase with $\mathrm{IC}_{50} \mathrm{~s}$ ranging from 0.8 to $12 \mu \mathrm{M}$ depending on the substrate and assay conditions. The compound was also an effective inhibitor of $E$. coli RNase HI and MLV RNase H. BBNH became a promising lead due to its expected potential as a multitarget drug.

Crystallographic studies carried out with a derivative of BBNH, $(E)$ 3,4-dihydroxy- $N^{\prime}$-((2-methoxynaphthalen-1-yl)methylene)benzohydrazide (DHBNH), showed that this compound binds $>50 \AA$ away from the RNase $\mathrm{H}$ active site, between the RT polymerase active site and the polymerase primer grip, in a pocket that overlaps in part with the NNRTI binding site (Himmel et al., 2006). Contacts with the side-chains of Asp186, Tyr188, Leu228 and Trp229 facilitate the interaction of the RT with the inhibitor (PDB file 2I5J). The effects of the drug in the RT
RNase $\mathrm{H}$ activity are attributed to alterations in the trajectory of the template-primer so that the RNase $\mathrm{H}$ is unable to cleave the RNA strand in RNA/DNA complexes when the inhibitor is bound to the RT (Himmel et al., 2006). In addition, $\mathrm{N}$-acyl hydrazone derivatives have also an impact on the stability of the HIV-1 RT heterodimer that results in a loss of function (Sluis-Cremer et al., 2002).

Very early in antiretroviral drug discovery, the structure of another HIV-1 enzyme, IN, member of the same polynucleotidyltransferase family, was partially solved (Dyda et al., 1994). HIV-1 IN catalytic domain showed strong structural similarities with the catalytic domain of RT RNase H, opening the possibility of designing dual-acting agents, that could target two different viral proteins at the same time, and in consequence decrease the possibility for selection of drug resistant variants (Esposito and Tramontano, 2013).

As a new target for antiretroviral therapy, multiple chemical scaffolds, especially the diketo and $\beta$-keto acids were used to develop specific HIV-1 IN inhibitors (Li et al., 2015). While BBNH, DHBNH, foscarnet and others can be considered allosteric inhibitors of HIV-1 RNase $\mathrm{H}$, diketo acids might sequester the $\mathrm{Mg}^{2+}$ ions required for RNase $\mathrm{H}$ activity in a similar way to compounds blocking the HIV-1 IN strand transfer activity. Thus, 4-[5-(benzoylamino)thien-2-yl]-2,4-dioxobutanoic acid (a thiophene diketo acid) (Fig. 6) inhibited RNase $\mathrm{H}$ activity with an $\mathrm{IC}_{50}$ of $3.2 \mu \mathrm{M}$, but was devoid of DNA polymerase inhibitory activity in enzymatic assays (Shaw-Reid et al., 2003). Nhydroxyimides such as the 2-hydroxyisoquinoline-1,3(2H,4H)dione (Fig. 6) showed a similar mechanism of action, but they also had some inhibitory activity against the RT DNA polymerase (Klumpp et al., 2003).

Two years later, RDS1643 (6-[1-(4-fluorophenyl)methyl-1 $H$-pyrrol2-yl)]-2,4-dioxo-5-hexenoic acid ethyl ester) (Fig. 6) was identified as the compound able to inhibit HIV-1 RT-associated RNase $\mathrm{H}$ in biochemical assays $\left(\mathrm{IC}_{50}\right.$ of $13 \mu \mathrm{M}$ ). RDS1643 was also active in cell culture, showing an $\mathrm{EC}_{50}$ of $14 \mu \mathrm{M}$ against wild-type HIV-1, and similar values against NNRTI-resistant mutants containing substitutions Y181C and K103N/Y181C (Tramontano et al., 2005). At the same time, it was reported that a hydroxylated tropolone isolated from the heartwood of the Western red cedar and known as $\boldsymbol{\beta}$-thujaplicinol (Fig. 6) was able to inhibit HIV-1 and HIV-2 RNases $\mathrm{H}$ at submicromolar concentrations (Budihas et al., 2005). Although $\boldsymbol{\beta}$-thujaplicinol was a relatively weak inhibitor of $E$. coli RNase $\mathrm{H}\left(\mathrm{IC}_{50}=50 \mu \mathrm{M}\right)$, it showed an $\mathrm{IC}_{50}$ of $5.7 \mu \mathrm{M}$ for human RNase H1, limiting its development as an efficient antiviral drug. As for diketo acids and N-hydroxyimides, Budihas et al. proposed that its mechanism of action would involve chelation of active site metal ions in the RNase $\mathrm{H}$ domain of the RT. Crystallographic studies showing $\beta$-thujaplicinol bound to the RNase $\mathrm{H}$ active site of HIV-1 RT 
<smiles>CC(C)(C)c1ccc(C(=O)N/N=C/c2c(O)ccc3ccccc23)cc1</smiles>

N-(4-tert-butylbenzoyl)-2-hydroxy1-naphthaldehyde hydrazone (BBNH)

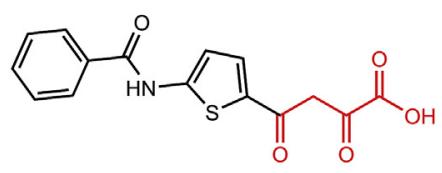

4-[5-(benzoylamino)thien-2yl]-2,4-dioxobutanoic acid<smiles>COc1ccc2ccccc2c1/C=N/NC(=O)c1ccc(O)c(O)c1</smiles><smiles>O=C1Cc2ccccc2C(=O)N1O</smiles>

2-hydroxyisoquinoline1,3(2H,4H)-dione

(E)-3,4-dihydroxy-N'-((2-methoxynaphthalen1-yl)methylene)benzohydrazide (DHBNH)<smiles>CCOC(=O)C(=O)CC(=O)/C=C/c1cccn1Cc1ccc(F)cc1</smiles><smiles>CC(C)c1ccc(O)c(=O)c(O)c1</smiles>

$\beta$-thujaplicinol

Fig. 6. Compounds representing early efforts in the development of HIV-1 RNase H inhibitors. Pharmacophores with chelating activity are shown in red.

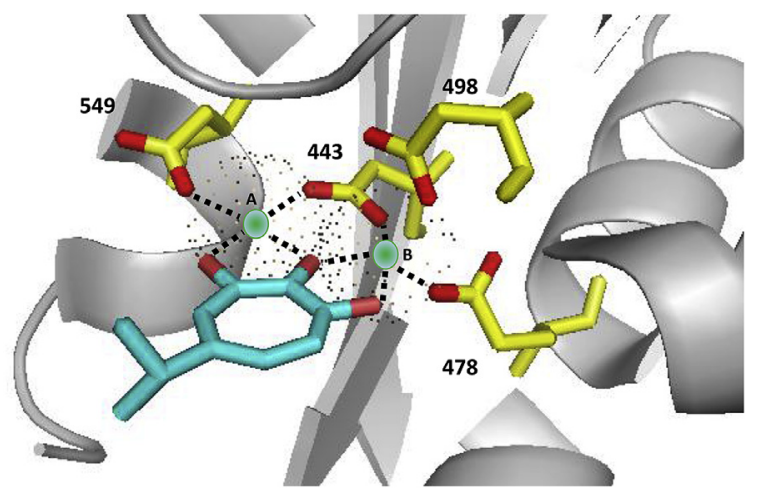

Fig. 7. Interactions of $\beta$-thujaplicinol at the HIV-1 RT RNase $\mathrm{H}$ catalytic site. Catalytic residues of the DEDD motif and the inhibitor are represented with yellow and blue sticks, respectively (oxygen atoms are shown in red). Divalent cations $\mathrm{A}$ and $\mathrm{B}$ and their potential interactions with the active site and $\beta$ thujaplicinol are shown with discontinuous black lines. The diagram was prepared with PyMOL using coordinates of the Protein Data Bank file 3K2P (Himmel et al., 2009).

and an isolated RNase $\mathrm{H}$ domain demonstrated that the tropolone forms a stable complex where the inhibitor binds catalytically essential RNase $\mathrm{H}$ active residues and chelates the $\mathrm{Mg}^{2+}$ ions required for catalysis (Himmel et al., 2009) (Fig. 7).

Since the discovery of RDS1643, $\beta$-thujaplicinol and DHBNH as effective active site and allosteric RNase $\mathrm{H}$ inhibitors, a number of additional chemotypes have been designed and extensively explored to discover novel RNase $\mathrm{H}$ inhibitors with $\mathrm{IC}_{50} \mathrm{~S}$ in the low micromolar or high nanomolar range (Tramontano and Di Santo, 2010; Wang et al., 2018c). Despite significant improvements, the efficacy of those molecules is limited by the shallow, open shape of the HIV RNase H catalytic groove which provides few contact sites for inhibitors other than interactions with the two metal ions (Billamboz et al., 2011). In the next section, we will describe major chemotypes identified in the last decade, and their inhibitory properties, dividing them in three groups: metal chelators, allosteric inhibitors and natural compounds.

\section{Metal-chelating HIV RNase $\mathrm{H}$ active site inhibitors: representative chemotypes and inhibitory activity}

The presence in the HIV-1 RNase $\mathrm{H}$ site of the highly conserved and essential DDE motif, comprising four carboxylate residues that coordinate two divalent cations, offers the possibility to target the active site by compounds possessing metal coordinating functions. All of them have a three oxygen pharmacophore necessary for their metalchelating activity, which is shared by approved IN inhibitors. Among them diketo acids, $\alpha$-hydroxytropolones, and $N$-hydroxyisoquinolinediones as well as hydroxylated heterocyclic compounds are probably the most widely used chemotypes for the design and development of compounds targeting viral RNases H. Most of the identified leads exhibit dual activity, being also able to inhibit HIV-1 IN, while in several cases a partial or even total selectivity for HIV-1 RNase $\mathrm{H}$ function has been obtained, providing valuable insights for the optimization of the lead compounds.

\subsection{Diketo acids (DKAs)}

DKA derivatives were first reported as chelators of the $\mathrm{Mg}^{2+}$ cofactors in the active site of influenza virus endonuclease (Tomassini et al., 1994), then identified as HIV-1 IN strand transfer inhibitors (Wai et al., 2000), and later tested against HIV-1 RNase H (Shaw-Reid et al., 2003, Sluis-Cremer et al., 2004; Tramontano et al., 2005). Given the high similarity between HIV-1 RNase $\mathrm{H}$ and IN, compounds bearing diketo acid moieties are often inhibitors of both activities of HIV-1. Several pyrrolyl DKA derivatives, having a quinolinonyl- or a pyrroylbased scaffold (Fig. 8), have been reported as RNase H inhibitors with dual activity against HIV-1 IN and RT-associated RNase H (Tramontano, 2006; Tramontano and Di Santo, 2010; Di Santo, 2011; Costi et al., 2013; Costi et al., 2014; Cuzzucoli Crucitti et al., 2015).

Among the pyrroyl DKAs, several RDS1643 analogues were developed, and studies on the mode of action of pyrroyl-ester/acid derivatives showed that esters displayed selectivity for HIV-1 RNase-H versus IN, while acid derivatives were more active against HIV-1 IN (Corona et al., 2014a; Cuzzucoli Crucitti et al., 2015). This difference in activity relies upon the electrostatic neutrality of the RNase $\mathrm{H}$ active site where four catalytic acid residues (Asp443, Glu478, Asp498, and Asp549) neutralize completely the four positive charges of the two $\mathrm{Mg}^{2+}$ ions. On the other hand, the IN active site contains only three acidic residues (Asp64, Asp116, and Asp152) and is positively charged, allowing the negatively charged acidic compounds to bind more favorably to the HIV-1 IN in comparison with the RNase H. In particular, RDS1759 (Fig. 8) was the first compound that inhibited HIV-1 replication selectively by blocking the RT-associated RNase $\mathrm{H}$ activity (Corona et al., 2014a). Indeed, RDS1759 bearing a chlorine atom at position 2 of the benzyl group, inhibited the RNase $\mathrm{H}$ activity with an $\mathrm{IC}_{50}$ value of 
Pyrrolyl Diketo Acid/Ester derivatives<smiles>[R1]OC(=O)C(=O)CC(=O)/C=C/c1cc([Hg])cn1[R2]</smiles><smiles>[R]OC(=O)/C(O)=C/C(=O)c1cn(C)c2cc(C(C)(C)C)ccc2c1=O</smiles><smiles>CCOC(=O)C(=O)CC(=O)/C=C/c1cccn1Cc1ccccc1Cl</smiles>

RDS1759<smiles>O=C(O)/C(O)=C/C(=O)c1cn(Cc2ccc(F)cc2)c2cc(N3CCCC3)ccc2c1=O</smiles>

Compound $7 \mathrm{~b}$<smiles>CCOC(=O)/C=C(\O)C(=O)/C=C/c1cn(-c2ccccc2)cc1C(=O)c1ccc(F)cc1</smiles>

Compound $6 f$<smiles>CC(=O)N1CCN(c2ccc3c(=O)c(C(=O)/C=C(\O)C(=O)O)cn(Cc4ccc(F)cc4)c3c2)CC1</smiles>

Compound 12d

Fig. 8. Chemical structures of representative diketo acids and ester derivatives active against HIV-1 RNase H. Chelating groups are shown in red.

7.3 $\mu \mathrm{M}$, showing remarkable selectivity against RNA-dependent DNA polymerase (RDDP) and IN strand transfer activities $\left(\right.$ IC $_{50} \mathrm{~S}>50 \mu \mathrm{M}$ and $>100 \mu \mathrm{M}$, respectively). Moreover, NMR and site-directed mutagenesis studies demonstrated the DKA interactions with highly conserved amino acid residues in the RNase H domain, Gln475, Asn474, and Tyr501 (Corona et al., 2014a,b). All of those residues are part of the so-called "RNase H primer grip", a highly conserved region that interacts with the DNA primer strand of an RNA:DNA substrate and may play a role in catalysis and RNA cleavage specificity. These interactions contributed critically to selective RNase $\mathrm{H}$ inhibition and effective targeting of HIV reverse transcription in cells $\left(\mathrm{EC}_{50}=2.1 \mu \mathrm{M}\right)$ without significant cytotoxicity.

Selective RNase H DKA inhibitors were reported later as able to block a multi-drug resistant HIV-1 RT (Schneider et al., 2016). Further studies on the pyrroyl-based scaffold of RD1759 led to the discovery of compound $6 \mathrm{f}$ that showed an $\mathrm{IC}_{50}$ value for RNase $\mathrm{H}$ of $1.8 \mu \mathrm{M}$ (Fig. 8) (Cuzzucoli Crucitti et al., 2015). Interestingly, 6f also inhibited HIV-1 IN strand transfer activity $\left(\mathrm{IC}_{50}=1.2 \mu \mathrm{M}\right)$ and was active against HIV-1 in cell culture, showing an $\mathrm{EC}_{50}$ of $20 \mu \mathrm{M}$ and a $\mathrm{CC}_{50}>50 \mu \mathrm{M}$.

Quinolinonyl DKA derivatives were also characterized among the first HIV-1 IN inhibitors, with a general structure containing a quinolinone ring, bearing a p-fluorobenzyl group as $N$ substituent, a DKA group (acid or ester) at position 3 , and a variable basic moiety at position 7 (Fig. 8) (Costi et al., 2014). These compounds were generally more active against IN, in particular the acid derivatives. Among them, a rather potent RNase $\mathrm{H}$ inhibitor was compound $\mathbf{7 b}$ (Fig. 8) that contained a pyrrolidine group in position 7 , and showed an $\mathrm{IC}_{50}$ of $5.1 \mu \mathrm{M}$ in enzymatic assays, while inhibiting viral replication with an $\mathrm{EC}_{50}$ of $14 \mu \mathrm{M}$ (Costi et al., 2014). Compound 7b also inhibited HIV-1 IN strand transfer activity with an $\mathrm{IC}_{50}$ or $0.028 \mu \mathrm{M}$. Compound 12d (Fig. 8) that contained an $\mathrm{N}$-acetyl piperazine instead of the pyrrolidine in the quinolinone ring also showed good inhibitory activity in enzymatic and cell-based assays (RNase $\mathrm{H} \mathrm{IC}_{50}=3.3 \mu \mathrm{M}$; IN strand transfer $\mathrm{IC}_{50}=0.08 \mu \mathrm{M}$; HIV-1 replication $\left.\mathrm{EC}_{50}=17 \mu \mathrm{M}\right)$. Among this class of inhibitors, no selective RNase $\mathrm{H}$ inhibitor has been reported so far.

\section{2. $\alpha$-hydroxytropolones ( $\alpha H T s$ )}

As discussed above, $\boldsymbol{\beta}$-thujaplicinol (Fig. 6 ) is the most extensively characterized $\alpha$-hydroxytropolone and one of the first reported HIV-1 RNase H inhibitors (Budihas et al., 2005). It inhibited HIV-1 RNase H in biochemical assays with an $\mathrm{IC}_{50}$ of $0.2 \mu \mathrm{M}$, but it was ineffective in reducing virus replication in cell-based assays. Of note, $\beta$-thujaplicinol was rather specific for RNase $\mathrm{H}$ inhibition and was found to be a weak inhibitor of the HIV-1 IN strand transfer reaction in the presence of $\mathrm{Mg}^{2+}$ (IC 50 of $20 \mu \mathrm{M}$ in biochemical assays) (Semenova et al., 2006).
Since then, several attempts were done to improve its potency and selectivity. Chung et al. (2011) described a series of 14 synthetic analogues of manicol. Among them some compounds were active against HIV-1 RNase $\mathrm{H}$ in the low micromolar range, while showing $\mathrm{EC}_{50}$ values ranging from $4.2 \mu \mathrm{M}$ (compound 8) to $42.1 \mu \mathrm{M}$ (compound 2), in HIV-1 replication assays. These compounds had very low cytopathic effect. Compound 1, shown in Fig. 9, exhibited the best profile with an $\mathrm{IC}_{50}$ of $0.82 \mu \mathrm{M}$ (RNase $\mathrm{H}$ activity assays), $\mathrm{EC}_{50}$ of $10.2 \mu \mathrm{M}, \mathrm{CC}_{50}>50 \mu \mathrm{M}$, and a selectivity index of 4.9 .

\subsection{Pyrimidine and hydroxypyridone carboxylic acids}

These inhibitors were obtained by following a similar approach to that followed with $\alpha$-hydroxytropolones. Thus, the chelating groups containing a DKA moiety were introduced in hydroxypyrimidine or hydroxypyridone rings (Fig. 9). The DKA chain is biologically labile, and a time-dependent decrease in activity has been reported in solution (Corona et al., 2014a). Therefore, more stable chelating groups were explored. Summa et al. (2004) showed that pyrimidinol carboxylic acids were stable substitutes for $\alpha, \gamma$-diketo acids, obtained as selective inhibitors of the hepatitis C virus (HCV) NS5B polymerase. Later, these molecules were investigated as scaffolds for the development of HIV RNase $\mathrm{H}$ inhibitors. The best compound of the series, designated as number 11 (Fig. 9) was a potent inhibitor of HIV-1 RNase $\mathrm{H}$ with an $\mathrm{IC}_{50}$ of $0.18 \mu \mathrm{M}$, and 288 times less active against human RNase H1 (Kirschberg et al., 2009). Unfortunately, the compound was unable to inhibit viral replication in cell culture. Given its remarkable potency, compound 11 interaction with the HIV-1 RNase H domain was later characterized by crystallization (Lansdon et al., 2011) confirming the $\mathrm{Mg}^{2+}$ coordination binding mode, and describing additional contacts between its aromatic moiety and the side chain of His539.

Taking into account that the hydroxypyridone carboxylate core was a good scaffold for the development of influenza endonuclease inhibitors (Fujishita et al., 2010), as well as the FDA-approved HIV IN strand transfer inhibitor dolutegravir (Johns et al., 2013), Kankanala et al. (2016) synthesized a series of $N$-substituted pyridonecarboxylic acid analogues that were found to be inhibitors of HIV-1 RNase H. Most of the hydroxypyridone carboxylate derivatives inhibited RNase $\mathrm{H}$ in the low micromolar range $\left(\mathrm{IC}_{50}=0.65-18 \mu \mathrm{M}\right.$ ), but analogues bearing a two-ring or a biaryl substituent at the N1 position showed enhanced potency, while those lacking any substituent or having phenyl groups at the same position were inactive (Kankanala et al., 2016). In addition, the esterification of the carboxylate group abrogated the inhibitory activity. Importantly, compound 10r, bearing a naphthyl group in N1 (Fig. 9) exhibited significant inhibitory activity in a cell-based antiviral assays with an $\mathrm{EC}_{50}$ of $10 \mu \mathrm{M}$. This compound also showed significant 


\section{$\alpha$-hydroxytropolone}<smiles>CCCCCN(CCCCC)CC(O)(O)C1CCc2c(c(C)cc(O)c(=O)c2O)C1</smiles>

\section{$N$-hydroxymide derivatives}<smiles>COC(=O)C1C(=O)N(O)C(=O)c2ccccc21</smiles>

\section{Methyl 2-hydroxy-1,3-dioxo- 1,2,3,4-tetra-hydroiso- quinoline-4-carboxylate (HID)}

\section{Hydroxypyrimidine and hydroxypyridone carboxylic acids}

\section{Chemotypes}<smiles>[R]n1cc(O)c(=O)c(C(=O)O)c1</smiles><smiles>[R]c1nc(O)c(O)c(C(=O)O)n1</smiles><smiles>O=C1Cc2ccc(-c3ccco3)cc2C(=O)N1</smiles>

YLC2-155<smiles>O=C(O)c1cn(Cc2ccc3ccccc3c2)cc(O)c1=O</smiles>

Compound 10r<smiles>O=C1Cc2cc(Cc3ccc(-c4ccccc4)cc3)ccc2C(=O)N1O</smiles>

Compound 20i

\section{Compound 11}<smiles>O=C(O)c1nc(Cc2c(Br)sc3ccc(Cl)cc23)nc(O)c1O</smiles>

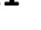
(1)

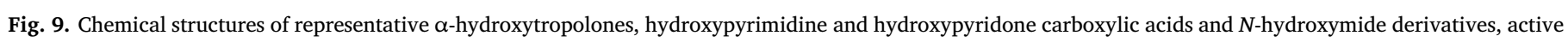
against HIV-1 RNase H. Chelating groups are shown in red.

RNase $\mathrm{H}$ inhibitory activity in enzymatic assays ( $\mathrm{IC}_{50} 2.7 \mu \mathrm{M}$ ), and was active in RDDP and IN strand transfer activity assays ( $\mathrm{IC}_{50} \mathrm{~S}$ of $8.5 \mu \mathrm{M}$ and $23 \mu \mathrm{M}$, respectively). An increase in potency of inhibition was achieved by adding a 4-sulphonamide diphenyl group at position N1. However, compound $10 \mathrm{y}$ showed an $\mathrm{IC}_{50}$ of $0.65 \mu \mathrm{M}$ in RNase $\mathrm{H}$ inhibition assays but was not active in viral replication assays.

The X-ray crystal structure of HIV RT in complex with compound $10 \mathrm{y}$ demonstrated that in addition to the interaction of the pyridone -OH group and the side-chain of His539, the 4-sulphonamide moiety provided additional contacts with residue Lys540 within the HIV-1 RT RNase $\mathrm{H}$ domain.

\subsection{N-hydroxyimide derivatives}

The relatively simple geometry of the $N$-hydroxyimide derivatives was initially investigated by Klumpp (2003) who showed that these chemotypes presented oxygen atoms for optimal interaction with two metal ions bound at a distance of 4-5 $\AA$ within the RNase $\mathrm{H}$ active site, and therefore explored these structures as scaffolds to design potent RNase $\mathrm{H}$ inhibitors. Then, it was reported that the prototypic $N$-hydroxyisoquinolinedione (HID) (Fig. 9) inhibited HIV-1 RNase H activity in the low micromolar range (Klumpp, 2003). The loss of activity caused by the substitution of the $\mathrm{OH}$ group by methoxy or amino groups demonstrated a simple pharmacophoric requirement that could consist on a chelating moiety included in a ring with fixed angles, that could ensure a stable anchor to the active site, coupled with aromatic substitutions to improve the affinity for the target.

Since then, the scaffold has been modified in several ways, by introducing substituents and lateral chains with the aim to improve potency and selectivity. Its chelating properties raised the possibility of closely exploring related HIV-1 enzyme targets such as the IN's strandtransfer and RT's RDDP activities (Gill et al., 2019). During the last few years, several interesting inhibitors that targeted preferentially RNase $\mathrm{H}$ function were identified. First, the 2-hydroxy-4-methoxycarbonylisoquinoline-1,3(2H,4H)-dione was described as a very potent RNase $\mathrm{H}$ inhibitor $\left(\mathrm{IC}_{50} 0.061 \mu \mathrm{M}\right)$ that in addition, was active against the viral IN $\left(\mathrm{IC}_{50}=4.7 \mu \mathrm{M}\right)$ and was able to block HIV-1 replication with an $\mathrm{EC}_{50}$ of $13.4 \mu \mathrm{M}$ (Billamboz et al., 2011).

Later on, the HID derivative 20i (Fig. 9), carrying a biaryl moiety connected to the chelating core via one atom linker (Vernekar et al., 2015) was found to be active against HIV-1 in viral replication assays $\left(\mathrm{EC}_{50}=3 \mu \mathrm{M} ; \mathrm{CC}_{50}>50 \mu \mathrm{M}\right)$, by inhibiting the RT-associated RNase $\mathrm{H}$ activity in the nanomolar range $\left(\mathrm{IC}_{50}=0.8 \mu \mathrm{M}\right)$. Compound $20 \mathrm{i}$ was also a good inhibitor of the RT RDDP activity $\left(\mathrm{IC}_{50}=1.6 \mu \mathrm{M}\right)$ but was inactive against the viral IN. The dual inhibition of RDDP and RNase $\mathrm{H}$ activities was later explored (Tang et al., 2017a) finding that some 5arylmethyl HID analogues had the best selectivity index for RNase $\mathrm{H}$, while among the 6-arylcarboxamide substituted HID analogues they were the most potent dual inhibitors, able to block both RDDP and RNase $\mathrm{H}$ in the submicromolar range. Unfortunately, no significant reduction in the cytopathic effect was observed at $10 \mu \mathrm{M}$ with any of these analogues.

YLC2-155 was a similar derivative that contained a furan structure instead of the biaryl moiety (Fig. 9). This compound inhibited RT DNA polymerase and RNase $\mathrm{H}$ activities with $\mathrm{IC}_{50} \mathrm{~s}$ of 2.6 and $0.65 \mu \mathrm{M}$, respectively (Kirby et al., 2017). Interestingly, a structurally related hydroxythienopyrimidinedione (compound 11d, Fig. 9) described by Kankanala et al. (2017), showed significant RNase H inhibitory activity at nanomolar concentrations $\left(\mathrm{IC}_{50}=0.04 \mu \mathrm{M}\right.$ ), and was active and noncytotoxic in viral replication assays $\left(\mathrm{EC}_{50}=7.4 \mu \mathrm{M} ; \mathrm{CC}_{50}>100 \mu \mathrm{M}\right)$. 
<smiles>[R]c1[nH]c(=O)n(O)c(=O)c1[R]</smiles>

Compound 45<smiles>CCc1c(CC2CCCCC2)n(COCc2ccc(F)c(F)c2)c(=O)n(O)c1=O</smiles>

Compound $4 f$<smiles>COc1cccc(-c2ccc(Nc3cc(=O)n(O)c(=O)[nH]3)cc2)c1</smiles>

Compound 11i<smiles>O=c1cc(Cc2ccc(-c3ccc(Cl)cc3Cl)cc2)[nH]c(=O)n1O</smiles>

Compound 17h<smiles>COc1cccc(-c2ccc(Sc3cc(=O)n(O)c(=O)[nH]3)cc2)c1</smiles>

Compound 13j<smiles>Cc1ccc(-c2ccc(C(=O)c3cc(=O)n(O)c(=O)[nH]3)cc2)cc1</smiles>

Compound 8a

Fig. 10. Chemical structures of representative $N$-hydroxypyrimidinediones active against HIV-1 RNase H. Chelating groups are shown in red.

In extended biochemical assays compound 11d did not inhibit the RT DNA polymerase, but was found to be a HIV-1 IN strand transfer inhibitor $\left(\mathrm{IC}_{50}=2.1 \mu \mathrm{M}\right)$, albeit less potent than against the viral RNase H.

\subsection{N-hydroxypyrimidinediones}

$N$-hydroxypyrimidinediones (HPD) share with compounds described above their metal-chelating function and a similar geometry (Fig. 10). HPD derivatives were initially designed as dual inhibitors of HIV RT and IN, in the attempt to unify the chemical properties of NNRTIs and IN strand transfer inhibitors (Tang et al., 2011). However, lead optimization of RNase $\mathrm{H}$ selective inhibitors produced compounds with improved potency and selectivity, but also molecules endowed with a dual-acting mode of action (Wu et al., 2016).

So far, compound 45 (Fig. 10) has been identified as the most potent dual-inhibitor of HIV-1 RNase $\mathrm{H}$ and IN, with $\mathrm{IC}_{50}$ s of $0.029 \mu \mathrm{M}$ and $0.021 \mu \mathrm{M}$, respectively. This compound is also active in viral replication assays with an $\mathrm{EC}_{50}$ of $0.015 \mu \mathrm{M}$ (Wu et al., 2016). Compound 45 has a carboxamide and a small alkyl group at positions C5 and C6, respectively. These substitutions in the pyrimidinedione ring turned the molecule into a potent inhibitor of both RNase H and IN, but it was unclear if the inhibition of the viral replication could be correlated with the block of both RNase $\mathrm{H}$ and IN. Interestingly, the fact that the compound was also able to inhibit raltegravir-resistant HIV-1 clones, suggested a promising prospective for its development.

The replacement of the phenyl ring at the C6 position with a cyclohexyl group generated a new subtype (Tang et al., 2017b) that had potent antiviral activity. Some of these derivatives were active against both HIV-1 RT activities (i.e. RDDP and RNase H). Among them, compound $4 \mathrm{f}$ (Fig. 10) was identified as an HIV-1 RNase $\mathrm{H}$ inhibitor $\left(\mathrm{IC}_{50}=1.7 \mu \mathrm{M}\right)$ and was active in viral replication assays showing an $\mathrm{EC}_{50}$ of $4.1 \mu \mathrm{M}$ and $\mathrm{CC}_{50}$ values higher than $100 \mu \mathrm{M}$. Compound $4 \mathrm{f}$ was inactive against RDDP and IN at concentrations above 10 and $100 \mu \mathrm{M}$, respectively. Interestingly, removal of the $\mathrm{OH}$ group on the pyrimidinedione ring (compound 11f) produced a complete reversal of the activity profile, losing the anti-RNase $\mathrm{H}$ effect in favor of anti-RDDP activity, while increasing the inhibitory potency in HIV-1 replication as well as its cytotoxicity (RNase $\mathrm{H}^{\mathrm{IC}} \mathrm{IC}_{50}=>10 \mu \mathrm{M}$; RT RDDP $\mathrm{IC}_{50}=0.82 \mu \mathrm{M} ; \quad \mathrm{IN} \quad \mathrm{IC}_{50}>100 \mu \mathrm{M}, \quad \mathrm{EC}_{50}=0.014 \mu \mathrm{M} \quad$ and $\left.\mathrm{CC}_{50}=29 \mu \mathrm{M}\right)$.

The HPD scaffold was simplified with the objective of finding specific RNase $\mathrm{H}$ inhibitors, by removing the substituents $\mathrm{N} 1$ and $\mathrm{C} 3$ and introducing at the $\mathrm{C} 6$ position a biaryl group using one-atom flexible linker (Tang et al., 2016, 2019; Wang et al., 2018a,b). The flexible oneatom linker at C6 appeared to profoundly influence the inhibitory activity both in vitro and in cellular assays:

(i) The - $\mathrm{NH}$ - and -O- linkers conferred submicromolar RNase H inhibition. Compound 11i, the best of this series bearing an methoxy-substituted biaryl group at $\mathrm{C} 6$ position (Fig. 10) inhibited RNase $\mathrm{H}$ in the submicromolar range $\left(\mathrm{IC}_{50}=0.15 \mu \mathrm{M}\right)$ and the RT RDDP activity in the low micromolar range $\left(\mathrm{IC}_{50}=7.3 \mu \mathrm{M}\right)$. Compound $11 \mathrm{i}$ also exhibited substantially reduced inhibition in HIV-1 IN strand transfer assays and had no significant cytotoxicity in cell viability assays (Tang et al., 2016). Unfortunately, the compound was not active in viral replication.

(ii) The $-\mathrm{CH}_{2}$ - linker produced a significant improvement of the scaffold, leading to potent inhibition of the RNase $H$ and significant antiviral activity (Wang et al., 2018a). Compound 17h (Fig. 10) inhibited the RNase $\mathrm{H}$ function in the low nanomolar range $\left(\mathrm{IC}_{50}=0.009 \mu \mathrm{M}\right)$ and showed $>1000$-fold selectivity against RT RDDP and IN. Compound 17h was a weak inhibitor of HIV-1 RT $\mathrm{RDDP}$ and IN strand transfer activities with $\mathrm{IC}_{50} \mathrm{~S}$ above $10 \mu \mathrm{M}$ in both cases.

(iii) Analogues with $a-S$ - linker had similar potency, but were less selective for RNase $H$. Compound $\mathbf{1 3} \mathbf{j}$, the best analogue within the series (Fig. 10), inhibited the RNase $\mathrm{H}$ with an $\mathrm{IC}_{50}$ of $0.005 \mu \mathrm{M}$, and was also active against RDDP and IN (RDDP IC $_{50}=10 \mu \mathrm{M}$; IN $\left.\mathrm{IC}_{50}=4.0 \mu \mathrm{M}\right)$. The compound inhibited viral replication with an $\mathrm{EC}_{50}$ of $7.7 \mu \mathrm{M}$ and was not cytotoxic at concentrations as high as $100 \mu \mathrm{M}$ (Wang et al., 2018b).

Recently, a more rigid version of the HPD scaffold, with a 


\section{Naphthyridinones}<smiles>CCOC(=O)c1c(O)c2cccnc2n(O)c1=O</smiles>

Compound 13<smiles>Nc1ccc(-c2ccc(Nc3cc(=O)n(O)c4ncccc34)cc2)cc1</smiles>

XZ460

\section{Hydroxypyridopyrimidinones and hydroxypyridopyrazinones}<smiles>O=c1nc(NCc2cc3ccccc3s2)c2cccnc2[nH]1</smiles>

GSK5750<smiles>O=c1nc(NCc2ccc(-c3ccccc3)cc2)c2cccnc2n1O</smiles>

Compound 22<smiles>N/C(=C\NCc1ccc(F)cc1)c1cccc(Nc2nc(=O)n(O)c3ncccc23)c1</smiles>

Compound IIA-2<smiles>COC(=O)c1c(Nc2ccc(-c3ccc(C#N)cc3)cc2)c2nccnc2n(O)c1=O</smiles>

Compound 7a

Fig. 11. Chemical structures of representative napthyridinones, hydroxypyridopyrimidinones and hydroxypyridopyrazinones active against HIV-1 RNase H.

nonflexible linker was developed in order to investigate reduced rotational freedom (Tang et al., 2019). The introduction of the carbonyl linker led to a series of compounds that retained good inhibitory activity against HIV-1 RNase $\mathrm{H}$, and were effective in antiviral assays. However, they were generally more toxic than the ones with the methyl linker. Compound 8a (Fig. 10), the best of the series, inhibited the RNase $\mathrm{H}$ with an $\mathrm{IC}_{50}$ of $0.021 \mu \mathrm{M}$, and was poorly active against the IN $\left(\mathrm{IC}_{50}=10 \mu \mathrm{M}\right)$. However, it was unable to inhibit RDDP activity at concentrations up to $10 \mu \mathrm{M}$. Compound $8 \mathrm{a}$ was active against HIV-1 in cell-based assays, showing an $\mathrm{EC}_{50}$ of $4.1 \mu \mathrm{M}$. However, it showed relatively high toxicity $\left(\mathrm{CC}_{50}=22 \mu \mathrm{M}\right)$ reducing its potential as a new drug candidate.

\subsection{N-hydroxynaphthyridinone (HNO)}

$N$-hydroxynaphthyridinones (HNO) were reported as the first bicyclic system with coordinating function able to inhibit HIV-1 RT (Su et al., 2010). Compound MK-1 (Fig. 11) inhibited HIV-1 RNase H activity $\left(\mathrm{IC}_{50}=0.11 \mu \mathrm{M}\right)$ and viral replication $\left(\mathrm{EC}_{50}=2.1 \mu \mathrm{M}\right)$ with no signs of toxicity up to $50 \mu \mathrm{M}$. The compound was co-crystallized within the RNase $\mathrm{H}$ active site, showing that its naphthyridine moiety coordinated, together with the carbonyl oxygen of residues Asp443, Glu478 and Asp498, and one of the ions of the catalytic pair. In addition to contacts with the metal ions, the inhibitor was found to interact with an RT loop containing residues Ala538 and His539. The scaffold was optimized by removing the carboxylic ester group and substituting an $\mathrm{OH}$ at position 4 with a series of biphenyl chains (Williams et al., 2010). A 4-p-aminomethyl-biphenyl analogue, designated as compound 13 (Fig. 11) was found to be potent and selective in biochemical assays (RNase H IC $50=0.045 \mu \mathrm{M}$; RDDP IC I0 $_{50}=13 \mu \mathrm{M}$; IN IC $50=24 \mu \mathrm{M}$ ) and showed antiviral efficacy in single-cycle viral replication assays
$\left(\mathrm{EC}_{50}=0.19 \mu \mathrm{M}\right), \quad$ although with a modest selectivity index $\left(\mathrm{CC}_{50}=3.3 \mu \mathrm{M}\right)$. Recently, a new series of compounds, specifically designed to bind the RNase $\mathrm{H}$ active site has been developed (Boyer et al., 2018). These compounds were tested using different substrates, to assess the impact on the different types of cuts performed by HIV-1 RNase H: 5' end-directed cleavage, 3' end-directed cleavage, internal cleavage, PPT cleavage and polymerase-dependent RNase H activity. Anti-RDDP activity was also tested.

The most potent compound of the series, XZ460 (Fig. 11) showed striking similarities with compound 13, with the 4 amino diphenyl group bound to the naphthyridinone ring with an amino linker. XZ460 inhibited HIV-1 replication with an $\mathrm{EC}_{50}$ of $94 \mathrm{nM}$, showing a therapeutic index of 26 . The compound was equally effective in inhibiting HIV-1-resistant mutants with altered susceptibility to IN inhibitors, NNRTIs, and NRTIs. Biochemical studies focusing on its mode of action showed that XZ460 inhibited all RNase H cleavages, as well as the RT polymerase activity. The same activity was investigated without two of the four RNase $\mathrm{H}$ catalytic carboxylic amino acids (using RTs bearing substitutions Asp443Ala and Asp539Ala). In the absence of $\mathrm{Mg}^{2+}$ in the RNase $\mathrm{H}$ active site that prevents XZ460 binding, RDDP activity is not inhibited, suggesting that RDDP inhibition occurs only when the compound binds the RNase $\mathrm{H}$ active site. Of note, XZ460 does not inhibit neither E. coli RNase HI nor human RNase H2, increasing its value as potential candidate for lead optimization.

\subsection{N-hydroxypyridopyrimidinones and N-hydroxypyridopyrazinones}

The 5-amino substituted pyridopyrimidinone scaffold was initially described in studies focused on its interaction with the RT-associated RNase H domain, using enzyme kinetics (Beilhartz et al., 2014). Compound GSK5750 (Fig. 11), that inhibited the HIV-1 RT-associated 
RNase $\mathrm{H}$ activity in the nanomolar range $\left(\mathrm{IC}_{50}=0.33 \mu \mathrm{M}\right)$ cannot access the $\mathrm{Mg}^{2+}$ ions in the RNase $\mathrm{H}$ active site when the template-primer is bound. In enzymatic assays GSK5750 has to be included in the reaction before adding the substrate. GSK5750 dissociates from the RNase $\mathrm{H}$ active site more slowly than $\beta$-thujaplicinol. This ability to form a long-lasting complex with HIV-1 RT, may in part neutralize the obstacle presented by the competing nucleic acid substrate, making the scaffold potentially interesting for further development.

A series of 5-amino substituted pyridopyrimidinone analogues were later described as novel scaffolds for obtaining HIV-1 RNase $\mathrm{H}$ inhibitors, and derived from results of virtual screening campaigns using libraries of two-metal binding compounds (Velthuisen et al., 2014). As reported for $\mathrm{N}$-hydroxynaphthyridinones, the best substituent to achieve remarkable anti-RNase $\mathrm{H}$ activity was a diphenyl moiety. Among the synthesized analogues, compound 22 (Fig. 11), bearing an aminomethyl-diphenyl substituent at position 5, showed nanomolar anti-RNase $\mathrm{H}$ activity in enzymatic assays $\left(\mathrm{IC}_{50}=10 \mathrm{nM}\right.$ ), while inhibiting HIV-1 replication in single-round replication assays with an $\mathrm{EC}_{50}$ of $0.2 \mu \mathrm{M}$. The compound showed some cytotoxicity $\left(\mathrm{CC}_{50}=4 \mu \mathrm{M}\right)$, but was active against the viral IN $\left(\mathrm{IC}_{50}=0.6 \mu \mathrm{M}\right)$. The evaluation of its metabolic stability revealed low membrane permeability and high clearance values.

The pyridopyrimidinone scaffold was further investigated with additional compounds obtained by replacing the aminomethyl-diphenyl group with a meta-triazole-benzene substituent, inspired by a series of hydroxy-quinazoline-2,4(1H,3H)-diones previously described as vaccinia virus and adenovirus replication inhibitors (Gao et al., 2017). Derivative IIA-2 (Fig. 11) inhibited HIV-1 and HIV-2 replication, with $\mathrm{EC}_{50}$ values of $0.92 \mu \mathrm{M}$ and $2.82 \mu \mathrm{M}$, respectively and with no toxicity up to $290 \mu \mathrm{M}$. The compound proved to inhibit HIV-1 IN strand transfer activity at $5 \mu \mathrm{g} / \mathrm{ml}$, but it was found to be a poor inhibitor of the RNase H activity of HIV-1 RT. Recently, Sun et al. (2018) described a series of $N$-hydroxypyridopyrazinone derivatives representing a new scaffold variant of the one described above. As suggested by the presence of the ester function at position 4, compounds of this series had a dual-inhibitor profile.

Compound 7a (Fig. 11) inhibited the RNase $\mathrm{H}$ with an $\mathrm{IC}_{50}$ of $1.77 \mu \mathrm{M}$, showing similar potency against IN $\left(\mathrm{IC}_{50}=1.18 \mu \mathrm{M}\right)$, while other derivatives were more active against one or the other of the two enzymes, suggesting that it would be possible to modulate the preferential target activity by changing the aromatic chain in position 5 . Unfortunately, none of the compounds was active in cell culture at concentrations lower than the toxic ones, that were, for all of them, in the low micromolar range.

\subsection{Dihydroxycoumarins}

Dihydroxycoumarins were identified by virtual screening and emerged as a promising scaffold for the development of HIV-1 RNase $\mathrm{H}$ inhibitors when compound F3284-8495 (7,8-dihydroxy-2-oxo- $2 \mathrm{H}$ chromen-4-yl)acetic acid) (Fig. 12), was co-crystallized within the HIV1 RNase $\mathrm{H}$ active site (Himmel et al., 2014). The compound coordinated the two metal ions within the active site, while making additional interactions with His539. When tested under conditions optimal for RNase $\mathrm{H}$ activity ( $\mathrm{pH} 8.0,10 \mathrm{mM} \mathrm{Mg}^{2+}$ ), the compound displayed an $\mathrm{IC}_{50}$ value of $1.1 \mu \mathrm{M}$, while when tested under putative physiological conditions ( $\mathrm{pH} 7.4,1 \mathrm{mM} \mathrm{Mg}{ }^{2+}$ ) its $\mathrm{IC}_{50}$ value was nearly 5 times higher $(4.8 \mu \mathrm{M})$, raising questions on the impact of the $\mathrm{pH}$ on the protonated state of the chelating agents. In the same work, the information obtained by the crystal structure was successfully used to design lead analogues, in which the ethanoic acid substituent was replaced with a variety of bulkier substituents anticipating that these might establish additional contacts with the RNase $\mathrm{H}$ domain and improve their inhibitory potency. The most effective derivative, F3385-2590 (Fig. 12), bearing a $N$-m-chlorophenyl piperazine substituent instead of the carboxylic group, showed a 6-fold increase in inhibitory potency compared to the parent compound under physiological conditions $\left(\mathrm{IC}_{50}=0.8 \mu \mathrm{M}\right.$ ). F3385-2590 also inhibited the DNA polymerase activity of the RT but with a lower potency. Docking calculations suggested that F3385-2590 interacts electrostatically with Trp535 or with Asn474 and Gln475, which are conserved residues of the RNase H "primer grip", and were known to interact with DKA inhibitors (Corona et al., 2014a). Despite promising results, no data were provided regarding inhibition of HIV replication in cell culture assays.

Most recently, a new set of structurally related 4-hydroxy- $2 \mathrm{H}, 5 \mathrm{H}$ pyrano(3,2-c)chromene-2,5-dione derivatives were described as efficient inhibitors of HIV-1 RNase $\mathrm{H}$ and IN strand transfer activities (Esposito et al., 2019). Among them, compound 7 was the most interesting derivative since it inhibits both activities with similar potency with $\mathrm{IC}_{50}$ values around $6.5 \mu \mathrm{M}$ for both enzymes.

\subsection{Benzenesulfonamides}

Derivatives of 4-(aryltriazolyl)-benzenesulfonamide emerged as novel scaffolds for RNase $\mathrm{H}$ inhibition as the result of focused screening campaigns using molecules specifically designed as metalloenzyme inhibitors (Pala et al., 2016). In this case, an interesting approach was used to adapt the electron density distribution of the inhibitor in order to have, at physiological conditions, a compound with higher affinity for the $\mathrm{Mg}^{2+}$ cofactors within the RNase $\mathrm{H}$ active site. The most active compound (10d) (Fig. 12) contains the sulfonamide group that plays a major role in the interaction with $\mathrm{Mg}^{2+}$. At $\mathrm{pH} 7.4$, the sulfonamide group of the compound would prevalently exist in a non-deprotonated form. Authors adopted a perfluorinating approach, that consists on the complete substitution of the hydrogens of an aromatic ring with fluorine atoms, dramatically increasing the acidity of ring substituents without significantly affecting the steric properties of the molecule. At $\mathrm{pH} 7.4$ deprotonation of the sulfamoyl group on fluorinated compounds should be favored, creating a negatively charged inhibitor that should be a better target for the RNase $\mathrm{H}$ active site. Indeed, compound 10d showed at $\mathrm{pH} 7.4$ an $\mathrm{IC}_{50}$ value against RNase $\mathrm{H}$ of $6.6 \mu \mathrm{M}$, ten times more potent than the one exhibited by the non-perfluorinated analogue in the same conditions. Compound $10 \mathrm{~d}$ was also active against the RDDP activity $\left(\mathrm{IC}_{50}=33.4 \mu \mathrm{M}\right)$ but was inactive against IN at concentrations as high as $100 \mu \mathrm{M}$.

\subsection{Galloyl derivatives}

The last chemotype that emerged as a source of HIV-1 RNase $\mathrm{H}$ inhibitors is represented by galloyl derivatives (Carcelli et al., 2017; Gao et al., 2019). The galloyl moiety was previously proposed as part of promising anti-IN compound (Desideri et al., 1998; Jiang et al., 2010). In their work, Carcelli et al. (2017) combined the galloyl function with the $N$-acylhydrazone scaffold, that was already proven to be worthy of optimization for the development of HIV-1 RNase H inhibitors (Gong et al., 2011), and that had been already investigated by the same group as a versatile source of chelating inhibitors of the influenza virus PA endonuclease (Carcelli et al., 2014, 2016).

Given the similarities among influenza endonuclease, HIV-1 RNase $\mathrm{H}$ and HIV-1 IN, a series of $\mathrm{N}$-acylhydrazone analogues was synthesized with the aim to identifying dual inhibitors of both HIV IN and RNase H. Interestingly, several of these compounds inhibit the RT-associated RNase $\mathrm{H}$ function in the low micromolar/high nanomolar range, being inactive against HIV-1 IN (Carcelli et al., 2017). The most potent inhibitor, compound 15 (Fig. 12), exhibited an $\mathrm{IC}_{50}$ of $0.9 \mu \mathrm{M}$, in conditions of competition with the substrate, since both inhibitor and substrate were added in solution before the enzyme, proving that the compound was not affected by substrate displacement, as for other classes of active site inhibitors. The inhibitor was not active against HIV-1 IN ( IC $\left._{50}=>100 \mu \mathrm{M}\right)$, showing a strong selectivity for the HIV-1 RNase $\mathrm{H}$. Within the same series, compound 18 bearing a 2,4-dihydroxyphenyl moiety connected to the hydrazone, was slightly less 
Dihydroxycoumarin derivatives<smiles>O=C(O)Cc1cc(=O)oc2c(O)c(O)ccc12</smiles>

F3284-8495

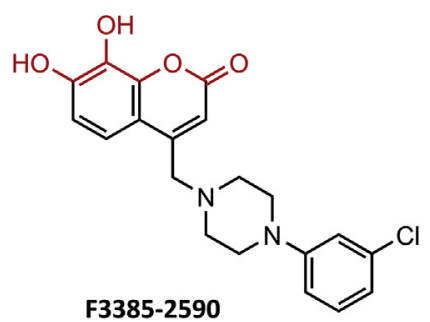

Benzenesulfonamide

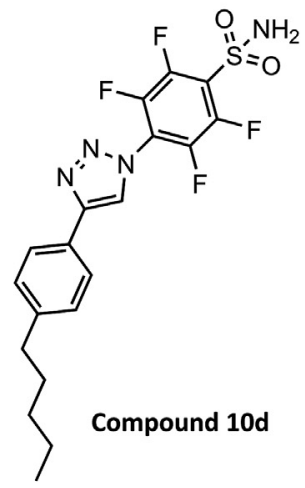

Galloyl derivatives<smiles>COc1cccc(/C=N/NC(=O)c2cc(O)c(O)c(O)c2)c1O</smiles>

Compound 15<smiles>Nc1ccc(S(=O)(=O)N2CCN(C(=O)c3cc(O)c(O)c(O)c3)CC2)cc1</smiles>

Compound II-25

Fig. 12. Chemical structures of representative dihydroxycoumarin, benzenesulfonamide and galloyl derivatives active against HIV-1 RNase H. Chelating groups are shown in red.

potent than compound 13 against RNase $\mathrm{H}\left(\mathrm{IC}_{50}=1.7 \mu \mathrm{M}\right)$. However, these molecules had a low selectivity index. At $25 \mu \mathrm{M}$, compound 18 showed 55-82\% inhibition of the HIV-1-induced cytopathic effect, but also showed some cytotoxicity at that concentration ( $\mathrm{CC}_{50} 61 \mu \mathrm{M}$ ) (Carcelli et al., 2017). Computational prediction of interactions within the RNase $\mathrm{H}$ domain suggested that the gallic moiety serves as a chelating motif against the metal cations, while the remaining atoms of the molecules accommodate inside a narrow pocket lined by residues Gly444, Glu449, Arg557, and Asn474, and the aromatic ring stacked between Arg448 and Arg557.

Recently, Gao et al. (2019) described a new series of galloyl derivatives containing a galloyl group connected with diversely substituted non-aromatic aliphatic rings (i.e. piperidine and piperazine). While all of the compounds showed to be inactive against the HIV-1 RDDP activity $\left(\mathrm{IC}_{50}>50 \mu \mathrm{M}\right)$, they were found to be active against the viral IN strand transfer activity. Compound II-25 (Fig. 12) was the most promising compound with an $\mathrm{IC}_{50}$ of $0.7 \mu \mathrm{M}$ against RNase $\mathrm{H}$. The compound was also effective against the viral IN in biochemical assays ( $>50 \%$ inhibition at $1 \mu \mathrm{M}$ ), thereby showing significant dual inhibitor efficiencies. The predicted binding mode of II-25 within the RNase $\mathrm{H}$ active site was found to be similar to that previously reported for $\beta$ thujaplicinol. Under the testing conditions, only one out of the three hydroxyl substituents of the galloyl group is deprotonated, so that the oxygen anion could interact with $\mathrm{Mg}^{2+}$, Arg557, and His539, while the phenolic hydroxyl group also shows potential interactions with $\mathrm{Mg}^{2+}$ although in this case via a water bridge. In addition, the terminal $\mathrm{NH}_{2}$ could form an additional hydrogen bond with His539. Unfortunately, II-25 did not inhibit viral replication in cell-based assays, probably due in part to its poor permeability through the cell membrane as shown in cell permeability assays.

\section{Allosteric RNase $H$ inhibitors}

Active site inhibitors are hard to develop due to off-target toxicity and inefficient competition with nucleic acid substrates. These facts justify alternative strategies to develop new inhibitors. One possibility is to develop allosteric inhibitors that bind close to the RNase $\mathrm{H}$ active site and modify catalysis by affecting subdomain and/or subunit dynamics. This strategy, however, was not built starting from a theoretical rational but raised as the direct consequence of experimental findings. Indeed, in the first decade of the twenty-first century high-throughput screening became the most popular approach to find new molecules able to inhibit HIV-1 RNase $\mathrm{H}$ function. This methodology led to the discovery of several classes of inhibitors whose precise mode of action was initially unknown. Structural methodologies such as co-crystallization and NMR allowed then to identify their binding sites. In some cases, the inhibitors were found to bind outside the RNase $\mathrm{H}$ active site and to behave in different ways. Allosteric RNase $\mathrm{H}$ inhibitors can be classified in three groups: (i) allosteric selective RNase H inhibitors; (ii) HIV-1 RT p66/p51 interface inhibitors; and (iii) dual inhibitors of both RT-associated enzyme functions (i.e. DNA polymerase and RNase $\mathrm{H}$ ).

\subsection{Allosteric selective RNase H inhibitors: hydrazones}

As mentioned before, the first report describing allosteric RNase $\mathrm{H}$ inhibitors was published in 2006, when Himmel and colleagues reported the crystal structure of HIV-1 RT bound to the hydrazone analogue DHBNH, that inhibited the HIV-1 RNase $\mathrm{H}$ activity with an $\mathrm{IC}_{50}$ of $0.5 \mu \mathrm{M}$, while being inactive against the RT DNA polymerase activity (Himmel et al., 2006). DHBNH binds the HIV RT between the DNA polymerase active site and the polymerase primer grip, in a pocket located > $50 \AA$ away from the RNase $\mathrm{H}$ active site. The new pocket was next to the NNRTI binding site and a possible access to NNRTI pocket could explain why DHBNH analogues bearing bulkier substituents could inhibit the RT's RDDP activity more efficiently, while retaining equivalent RNase $\mathrm{H}$ inhibition ability. However, in that case, a second binding site close to the RNase $\mathrm{H}$ active site was not excluded, since RNase $\mathrm{H}$ inhibition was fully retained even in presence of saturated concentrations of nevirapine that should prevent DHBNH binding. It was hypothesized that DHBNH binding could alter the positioning of the RNA:DNA hybrid in the RT, possibly modifying the nucleic acid trajectory towards the RNase $\mathrm{H}$ catalytic site.

The same pocket was later described in a co-crystal of HIV-1 RT with the RNase H inhibitor MK3 (Su et al., 2010). The same compound was also co-crystallized within the RNase $\mathrm{H}$ active site of the HIV-1 RT RNase H isolated domain, p15. MK3 (Fig. 13) showed a mode of action that was $\mathrm{Mg}^{2+}$ dependent. In that case, authors agreed to conclude that this last binding was the most relevant for the inhibitory activity (Su et al., 2010).

Since then, the search for novel binding sites was pursued by combining biochemical and computational techniques. In 2011, compound BHMP03 (Fig. 13) was identified as an HIV-1 RNase $\mathrm{H}$ inhibitor $\left(\mathrm{IC}_{50}=0.4 \mu \mathrm{M}\right)$ that was inactive in RDDP activity assays $\left(\mathrm{IC}_{50}>10 \mu \mathrm{M}\right)$ (Felts et al., 2011). The binding site of this compound was centered on the p66 residue Gln507, as was later confirmed by sitedirected mutagenesis and NMR studies (Gong et al., 2011; Christen 
A

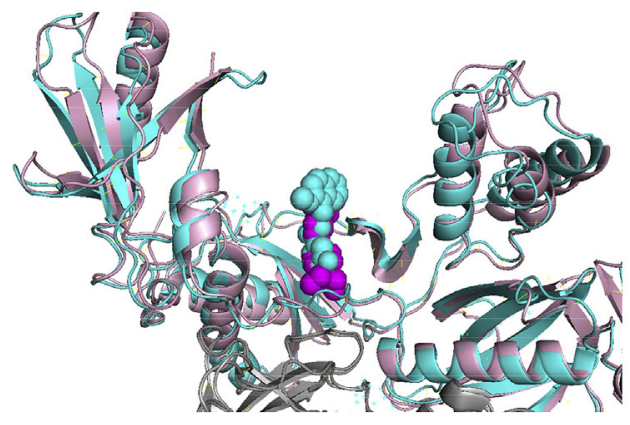<smiles>CCOC(=O)C1C(=O)N(O)c2ncc(Oc3ccc(N(CC)CC)cc3)cc2C1O</smiles><smiles>O=C(O)c1ccc(-c2cccc(C=NC(=O)c3ccc(O)c(O)c3)c2)cc1</smiles>

B

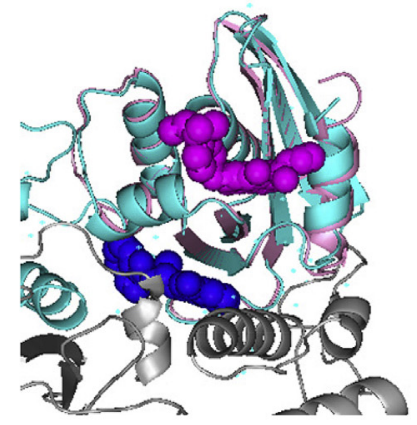

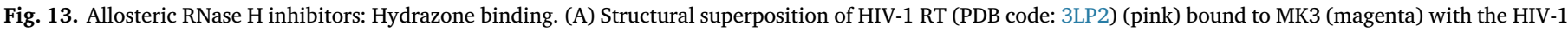

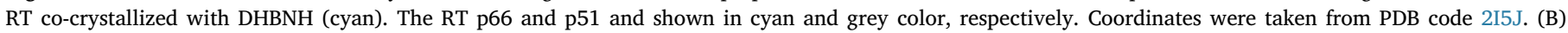

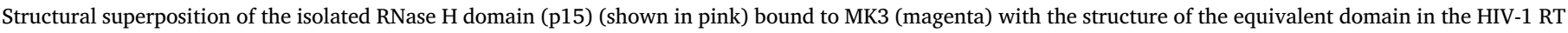

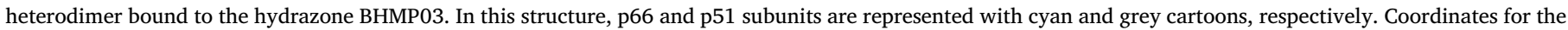

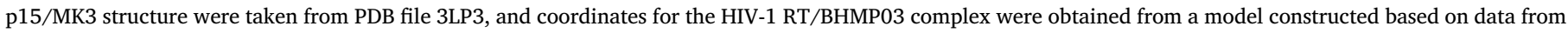
PDB file 2I5J. Adapted from Felts et al. (2011).

et al., 2012). NMR studies showed that hydrazone derivatives bind to a site located between the RNase $\mathrm{H}$ active site and the region encompassing $\alpha$-helices B and D in the RNase $\mathrm{H}$ domain, while site-directed mutagenesis studies revealed that the amino acid substitution A502F conferred resistance to BHMP03 (Christen et al., 2012).

\subsection{HIV-1 RT p66/p51 interface inhibitors: catechol-containing thienopyrimidinones}

Vinylogous ureas constitute a class of inhibitors identified by highthroughput screening. The most relevant compound in this class is NSC7 27447 (2-amino-5,6,7,8-tetrahydro-4H-cyclohepta[b]thiophene3-carboxamide), characterized as an HIV-1 RNase $\mathrm{H}$ inhibitor with an IC $_{50}$ of $2 \mu \mathrm{M}$, and showing some selectivity against human RNase H1 $\left(\mathrm{IC}_{50}=10.6 \mu \mathrm{M}\right)$ and $E$. coli RNase $\mathrm{H}\left(\mathrm{IC}_{50}>100 \mu \mathrm{M}\right)$ (Wendeler et al., 2008).

NSC727447 binding to HIV-1 RT was investigated by protein footprinting and mass spectrometry, and revealed that $\mathrm{p} 51$ thumb residues Cys280 and Lys281, located in $\alpha$-helix H, were implicated in the inhibitor binding, supporting the hypothesis that vinylogous ureas could interrupt catalysis by altering active site geometry. The scaffold was further developed to obtain a selective RNase $\mathrm{H}$ inhibitor, designated as compound 16 (Fig. 14A), that showed an $\mathrm{IC}_{50}$ of $0.86 \mu \mathrm{M}$ in RNase $\mathrm{H}$ inhibition assays, but without any effect on the enzyme's RDDP activity (Chung et al., 2010). Notably, the insertion of the catechol moiety as substituent in the thienopyrimidinone ring (Masaoka et al., 2013) led to analogues able to inhibit viral replication in cell culture. The best candidate (compound 24 of that series) showed an $\mathrm{IC}_{50}$ of $0.49 \mu \mathrm{M}$ in RNase $\mathrm{H}$ inhibition assays, and was effective in viral replication assays ( $\mathrm{EC}_{50}$ of $1.9 \mu \mathrm{M} ; \mathrm{CC}_{50}$ of $11.2 \mu \mathrm{M}$; selectivity index of 5.9). Thermal denaturation studies showed that compound 24 (Fig. 14) decreased the RT heterodimer $T_{\mathrm{m}}$ by more than $5{ }^{\circ} \mathrm{C}$, destabilizing its structure. Based on the open conformation of thienopyrimidinones, cycloheptathiophene-3-carboxamides were developed as potential inhibitors (Corona et al., 2016a). Among them, compound 33 (Fig. 14) inhibited the RNase $\mathrm{H}$ function with an $\mathrm{IC}_{50}$ of $0.84 \mu \mathrm{M}$, showing $>25$-fold selectivity for the RNase $\mathrm{H}$ activity versus the RDDP function.

Most recently, the scaffold was further investigated by substituting the pyrimidinone ring with a [1,3]oxazin-4-one, and introducing several ring types (Massari et al., 2019). All the catechol derivatives characterized by a tricyclic scaffold showed the ability to inhibit also the RDDP activity, perhaps because of a more planar conformation similar to some NNRTIs, conferred dual inhibitory activity. The analogues bearing a bicyclic scaffold were the compounds showing higher selectivity for the RNase H. Compound 22 (Fig. 14) was the most potent inhibitor of both RNase $\mathrm{H}$ and RDDP functions, with $\mathrm{IC}_{50}$ of $0.53 \mu \mathrm{M}$ and $2.90 \mu \mathrm{M}$, respectively. Molecular modelling combined with site-directed mutagenesis studies validated the hypothesis proposing that the compound binds to the HIV-1 RT p66/p51 interface, although the anti RDDP activity could be also attributed to the possible binding of compound 22 to the NNRTI pocket. Unfortunately, none of the compounds inhibited viral replication at concentrations lower than those found to be cytotoxic ( $\mathrm{CC}_{50}$ values ranging from 27 to $300 \mu \mathrm{M}$ ).

10.3. Dual inhibitors of RT-associated enzymatic activities DNA polymerase and RNase $H$

Since the discovery of the first molecules able to block two viral enzymatic functions, the development of dual inhibitors appeared as a fascinating possibility to develop effective drugs less susceptible to selection of resistant variants. In this context, the RT is the perfect target since it possesses two distinct enzymatic functions and catalytic sites that proved to be strongly interconnected, as well as a large molecular structure with several potential allosteric binding pockets.

The allosteric dual RNase H/RDDP inhibition property has been described for scaffolds characterized by a central functionalized core containing moieties able to donate or accept hydrogen bonds, either linear or made by heterocyclic rings linked to diverse substituted aromatic portions (Distinto et al., 2013; Meleddu et al., 2014, 2017; Corona et al., 2016b, 2017). The first lead compound of this class, an hydrazoindolin-2-one derivative, was identified by a ligand-based virtual screening using DHBNH as a first query (Distinto et al., 2012). It was active against both RT-associated RNase $\mathrm{H}$ and RDDP functions in the low micromolar range (Distinto et al., 2012). The scaffold, then was explored to create a number of variants among which are the 1,3-diarylpropenones and isatine thiazoline hybrids. The best compound of this type is EMAC2005 that bears a diphenyl moiety (Fig. 14C). EMAC2005 inhibited HIV-1 RNase H and RDDP activities in the low micromolar range with $\mathrm{IC}_{50}$ values of 6 and $4 \mu \mathrm{M}$, respectively. However, it was unable to inhibit HIV-1 replication (Meleddu et al., 2014). The same diphenyl moiety incorporated onto $N$-methyl-thiazoline hybrids (e.g. EMAC3056) led to a modest (2-fold) loss of potency (Meleddu et al., 2015), while other isatin-thiazoline analogues of the same series showed consistent inhibition of both RT-associated enzymatic activities.

The most potent dual inhibitor RMNC6 (Fig. 14C) showed IC 50 values of $1.3 \mu \mathrm{M}$ and $9.8 \mu \mathrm{M}$ for RNase $\mathrm{H}$ and RDDP, respectively, and its binding to RT was investigated by molecular modelling, and subsequently validated by site-directed mutagenesis experiments (Corona et al., 2016b). Results led to propose that the compound could bind to 
A<smiles>Cc1sc2nc(-c3ccc([N+](=O)[O-])cc3)[nH]c(=O)c2c1C</smiles>

Compound 16<smiles>CCCc1c(C)sc2nc(-c3ccc(O)c(O)c3)[nH]c(=O)c12</smiles>

Compound 24<smiles>O=c1oc(-c2ccc(O)c(O)c2)nc2sc3ccccc3c12</smiles>

Compound 22<smiles>O=C(Nc1sc2c(c1C(=O)Nc1ccccn1)CCCCC2)c1ccc(O)c(O)c1</smiles>

B

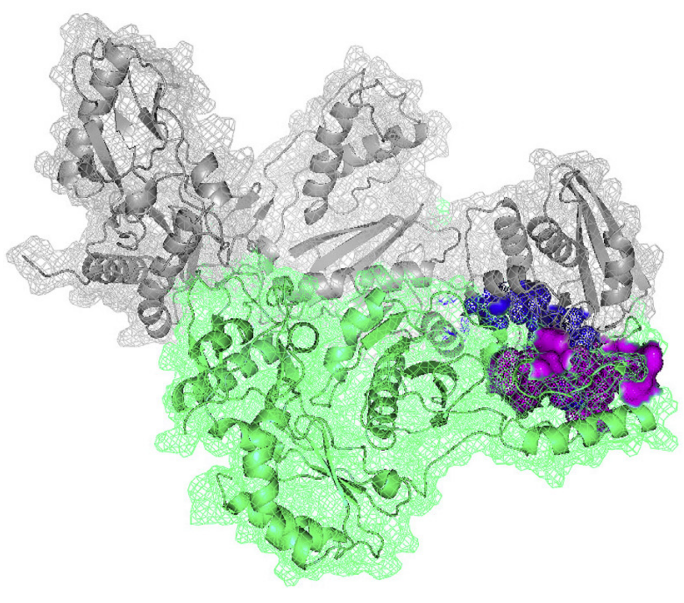<smiles>COc1c(/C=C/C(=O)c2ccc(-c3ccccc3)cc2)ccc2ccccc12</smiles>

EMAC2005

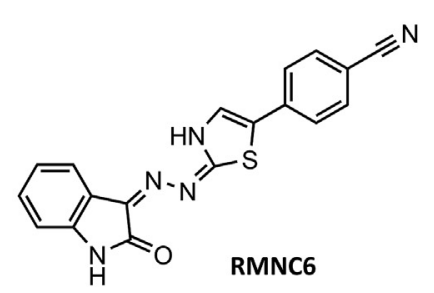

RMNC6

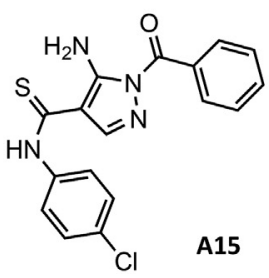

Fig. 14. Allosteric RNase H inhibitors interfering with RT heterodimerization and with dual activity against RNase $H$ and RDDP. (A) Structures of representative thienopyrimidinones interfering with HIV-1 RT heterodimerization. (B) HIV-1 RT heterodimeric structure showing the location of amino acid residues in thienopyrimidinone binding. RT subunits are shown in grey (p66) and green (p51). Compounds 16 and 24 bind in a hydrophobic pocket next to the RNase H active site, closed by p51 $\alpha$-helix H (magenta). Compounds 22 and 33 are reported to interact with adjacent residues on the Gln500 pocket (blue). (C) Representative allosteric inhibitors with dual activity against HIV-1 RNase $\mathrm{H}$ and RDDP.

two different RT allosteric pockets: one located in the DNA polymerase domain (partially overlapping the NNRTI pocket) already described for hydrazones and, the second overlapping the binding pocket centered at Gln500 and located below the RNase $\mathrm{H}$ active site, close to the p66/p51 interface (Corona et al., 2016b) (Fig. 14B). Enzymatic studies showed that RMNC6 interferes with efavirenz (an approved NNRTI) in its binding to the RT DNA polymerase domain, although NNRTI resistanceassociated mutations such as $\mathrm{K} 103 \mathrm{~N}, \mathrm{Y} 181 \mathrm{C}$ and $\mathrm{Y} 188 \mathrm{~L}$ had a minor impact on RT susceptibility to RMNC6. In addition, RMNC6 efficiently inhibited the polymerase activity of HIV-1 group O RT, naturally resistant to NNRTIs (Quiñones-Mateu et al., 1997; Menéndez-Arias et al., 2001), confirming that the activity was unrelated to potential interactions of RMNC6 with the NNRTI binding pocket.

The same pharmacophoric requirements for allosteric dual RNase H/RDDP inhibitors were applied to the synthesis of pyrazole-carbothioamide analogues endowed with the same dual site/dual inhibition mode of action, previously described for RMNC6 (Corona et al., 2017). Compound A15 (Fig. 14C), that blocked both RT-associated enzimatic functions, was more effective against RNase $\mathrm{H}$ than against the RT's RDDP activity ( $\mathrm{IC}_{50}$ of $7 \mu \mathrm{M}$ and $17 \mu \mathrm{M}$, respectively). It was also active in cell culture, but it showed a poor selectivity value $\left(\mathrm{EC}_{50}\right.$ $25 \mu \mathrm{M}$; $\left.\mathrm{CC}_{50} 44 \mu \mathrm{M}\right)$. Site-directed mutagenesis studies confirmed the dual site inhibition, since substitutions in the NNRTI binding site (i.e. V108A) and the Gln500 pocket (i.e. A502F) had a remarkable impact on the potency of A15, producing increases of around 10-fold in the $\mathrm{IC}_{50}$ obtained in RNase $\mathrm{H}$ inhibition assays.

\section{Natural products as HIV RNase $\mathrm{H}$ inhibitors}

Natural extracts have been investigated while searching for innovative chemotypes valuable against many targets. This approach has been applied to HIV-1 RNase $\mathrm{H}$ while searching for natural extracts with promising characteristics (Kharlamova et al., 2009). Thus, Esposito et al. (2016) have shown that extracts of Rheum palmatum and Rheum officinale can inhibit the HIV-1 RT-associated RNase H activity. Among the isolated constituents found in those preparations, sennoside A (Fig. 15) was found to inhibit both RT-associated activities (i.e. DNA polymerase and RNase H). Interestingly, sennoside A was less potent when tested on mutant HIV-1 RTs containing the single-amino acid substitutions K103N, Y181C, Y188L, N474A and Q475A, suggesting the involvement of two RT binding sites for its antiviral activity. Sennoside A inhibited HIV-1 replication with an $\mathrm{EC}_{50}$ of $9 \mu \mathrm{M}$ in the absence of cytotoxicity. Although this compound was also active against the HIV-1 IN strand transfer activity, viral DNA production analyzed by qPCR and time-of-addition antiviral assays showed that sennoside A targets the HIV-1 reverse transcription process, turning this agent into a promising scaffold for further development of RT dual inhibitors (Esposito et al., 2016).

A different behavior was observed with kuwanon-L (Fig. 15), a natural product extracted from the roots of Morus nigra, exerting its overall antiviral activity through binding to multiple viral targets (Martini et al., 2017). Indeed, this compound inhibited RNase $\mathrm{H}$ with an IC $_{50}$ of $0.57 \mu \mathrm{M}$, the RDDP activity with an $\mathrm{IC}_{50}$ of $0.99 \mu \mathrm{M}$, and the IN strand transfer activity with an IC $\mathrm{C}_{50}$ value of $22 \mu \mathrm{M}$. In phenotypic assays, kuwanon-L was found to inhibit HIV-1 replication with an $\mathrm{EC}_{50}$ of $1.9 \mu \mathrm{M}$, having no toxicity at concentrations as high as $20 \mu \mathrm{M}$. Interestingly, time-of-addition experiments showed an unusual profile with a sigmoidal curve, indicating that the compound was losing potency firstly, but not completely, during the reverse transcription step, then the retained partial inhibition was completely lost during the integration step, proving that the compound was exerting its inhibitory activity actually hitting two different viral targets, although the binding mode on HIV-1 RT was not further investigated.

Further studies showed that Ocimum sanctum L. leaves also 


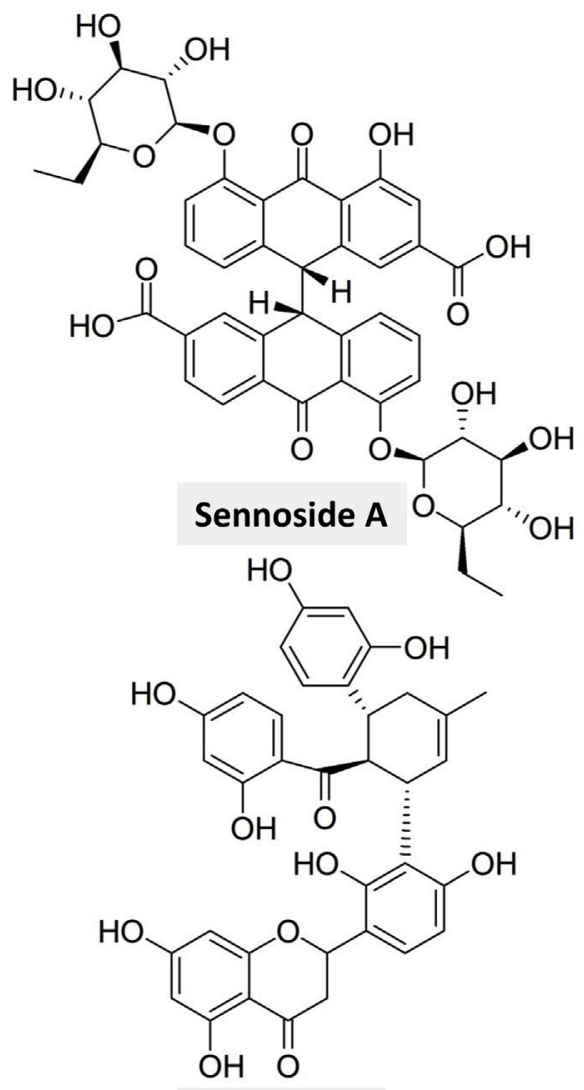

Kuwanon L<smiles>CCCCCCC/C=C/CCCCCCCCCCNC(=O)/C=C/c1ccc(O)c(O)c1</smiles><smiles>C/C(=C\Cc1c(O)cc(O)c(C(=O)C(C)C)c1O)CCC(O)C(C)C</smiles>

Compound 1<smiles>CCC(C)C(=O)c1c(O)cc(O)c(C/C=C(\C)CCC(O)C(C)C)c1O</smiles>

Compound 2<smiles>C=C(C)C(O)CC/C(C)=C/Cc1c(O)cc(O)c(C(=O)C(C)CC)c1O</smiles>

Compound 3

Fig. 15. Structures of HIV-1 RNase H inhibitors derived from natural compounds.

contained an HIV-1 RNase $\mathrm{H}$ inhibitor. This compound was a ferulaldehyde bearing a catechol moiety that showed an $\mathrm{IC}_{50}$ of $2.4 \mu \mathrm{M}$ in enzymatic assays (Sonar et al., 2017). Among the synthetic derivatives of this compound, $N$-oleylcaffeamide (18f) (Fig. 15) showed the higher inhibitory activity towards both RNase $\mathrm{H}$ and RDDP functions of HIV-1 RT with IC $_{50}$ values of $0.68 \mu \mathrm{M}$ and $2.3 \mu \mathrm{M}$, respectively (Sonar et al., 2017). Its effect on viral replication and eventual cytotoxicity were not determined. Most recently, Onopordum illyricum L. (Sanna et al., 2018a) and Hypericum scruglii (Sanna et al., 2018b) were also reported to be promising sources of anti-HIV-1 molecules. Among them, 1,5-dicaffeoylquinic acid from Onopordum Illyricum $L$. showed an interesting profile as dual inhibitor of RT-associated RNase $\mathrm{H}$ and IN strand transfer activities ( $\mathrm{IC}_{50}$ values of $16.9 \mu \mathrm{M}$ and $0.5 \mu \mathrm{M}$, respectively), proving to be not cytotoxic at concentrations as high as $50 \mu \mathrm{M}$.

The analysis of the effect of components of Hypericum scruglii (Sanna et al., 2018b), revealed that three prenylated phloroglucinols (Fig. 15), were able to inhibit HIV-1 replication with $\mathrm{EC}_{50}$ values ranging from 3.5 to $8 \mu \mathrm{M}$ and $\mathrm{CC}_{50}$ values above $50 \mu \mathrm{M}$. All of them were able to inhibit the RT-associated RNase $\mathrm{H}$ in the low micromolar range. The most potent molecule was compound 2 that inhibited the activities of the viral RNase $\mathrm{H}\left(\mathrm{IC}_{50}=4.1 \mu \mathrm{M}\right)$, the $\mathrm{RDDP}\left(\mathrm{IC}_{50}=12.3 \mu \mathrm{M}\right)$ and the IN $\left(\right.$ IC $\left._{50}=7.4 \mu \mathrm{M}\right)$. The same behavior was observed with all the described phloroglucinols. As reported for sennoside A, despite the anti-IN activity shown by these compounds, they seem to target reverse transcription in cell culture, without affecting viral integration.

\section{Active site human HBV RNase $H$ inhibitors}

Low-throughput screening assays using recombinant human HBV RNase $H$ have allowed the identification of a number of small molecules showing some inhibitory activity in enzymatic assays, as well as in viral replicon systems. The active compounds were derivatives of chemotypes known to be effective also against HIV-1 RNase $H$, such as $\alpha$ hydroxytropolones and $N$-hydroxyimides ( $N$-hydroxyisoquinolinediones, $N$-hydroxypyridinediones and napthyridinones) (Tavis et al., 2019) (Fig. 16). In general, HBV RNase H inhibitors were also active against human RNase H1, although some of them were ten times more potent against the viral enzyme.

$\beta$-thujaplicinol (Fig. 6) and its derivatives, and 2-hydroxyisoquinoline-1,3(2H,4H)-diones were the small molecules showing the highest selectivity (Hu et al., 2013; Cai et al., 2014; Lu et al., 2015). Hydroxylated tropolones were found to be effective inhibitors of HBV replication in cell-based assays with $\mathrm{EC}_{50}$ values in the submicromolar to low micromolar range, with $\beta$-thujaplicinol showing an $\mathrm{EC}_{50}$ of $1.0 \mu \mathrm{M}$ (Lu et al., 2015; Lomonosova et al., 2017). Although some of those compounds were found to be active against RNases $\mathrm{H}$ of HBV genotypes C and D (Lu et al., 2015), their efficacy was limited by their cytotoxicity. However, quantitative structure-activity relationships showed that reducing their lipophilicity and avoiding larger substitutions in their structure could ameliorate the efficacy problems (Lomonosova et al., 2017). Interestingly, among the $N$-hydroxyimide derivatives tested in HBV replication assays, the best $N$-hydroxyisoquinolinedione derivative, compound 86 (Fig. 16), had an $\mathrm{EC}_{50}$ of $1.4 \mu \mathrm{M}$ and a $\mathrm{CC}_{50}$ of $99 \mu \mathrm{M}$, while Edwards et al. (2019) have recently identified a more potent $\mathrm{N}$-hydroxypyridinedione derivative, compound A23, with an $\mathrm{EC}_{50}$ of $0.11 \mu \mathrm{M}$ and a $\mathrm{CC}_{50}$ of $33 \mu \mathrm{M}$ resulting in a good selective index. In addition, in a screening of related compounds using a cell-based HBV replication assay Huber et al. (2017) have identified two 3'-hydroxypyrimidine-2,4-diones with less potent inhibitory activity $\left(\mathrm{EC}_{50} \mathrm{~s}\right.$ in the range of 5.5-8.0 $\mu \mathrm{M})$ but low toxicity $\left(\mathrm{CC}_{50}>100 \mu \mathrm{M}\right)$. While no direct experimental evidence of RNase $\mathrm{H}$ inhibition by these compounds was provided, other biochemical studies have shown HBV 


\section{$\alpha$-hydroxytropolones}<smiles>CC(=O)c1cc(O)c(=O)c(O)cc1C</smiles>

110
280

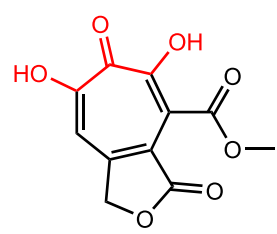

$\boldsymbol{N}$-hydroxyimide derivatives

$\mathrm{N}$-hydroxypyridinediones<smiles>C/C(=N\c1ccccc1N)c1c(C)cc(=O)n(O)c1O</smiles>

208<smiles>C/C(=N\OCc1ccc(F)cc1)c1c(C)cc(=O)n(O)c1O</smiles>

A23

\section{$N$-hydroxypyrimidinedione}<smiles>O=C(Nc1ccc2c(c1)C(=O)N(O)C(=O)C2C(=O)NCc1ccc(F)cc1)c1ccccc1</smiles>

Fig. 16. HBV RNase $\mathrm{H}$ inhibitors. Chelating groups are shown in red.

RNase $\mathrm{H}$ inhibition by $N$-hydroxypyridinediones also blocks the synthesis of plus-strand DNA and causes the accumulation of RNA/DNA heteroduplexes in viral capsids (Edwards et al., 2017).

Suppression of HBV replication has been observed in chimeric mice carrying humanized livers after treatment with $N$-hydroxypyridinedione or $\alpha$-hydroxytropolone derivatives (compounds $\mathbf{1 1 0}$ and 208; Fig. 16) (Long et al., 2018). These results, that were further confirmed for $\mathrm{HBV}$ genotype A and $\mathrm{C}$ isolates using the $\mathrm{N}$-hydroxypyridinedione derivative compound 208, confirmed that indeed HBV replication can be suppressed in vivo with specific RNase $\mathrm{H}$ inhibitors, thereby further validating the enzyme as a target for antiviral drug development. Pharmacological studies indicate that HBV RNase $\mathrm{H}$ inhibitors of different chemotypes are synergistic with each other as well as with lamivudine. However, for many HBV RNase H inhibitors, solubility problems, poor membrane permeability and low stability in hepatocytes still pose an important limitation for their further development.

\section{Perspectives and future developments}

During the last twenty years, significant steps have been put forward in the identification of effective RNase $\mathrm{H}$ inhibitors, and here we have analyzed the progresses made on HIV-1 and HBV. As discussed throughout this review article, HIV-1 RNase $\mathrm{H}$ has been the most extensively studied target and several inhibitors with nanomolar activity in enzymatic assays have been recently identified. However, there are no molecules in clinical trials, or even under evaluation in animal models, enlightening the difficulties that still have to be overcome in this research field.
The search for HBV ribonuclease $\mathrm{H}$ inhibitors started more recently and took advantage from the work done on the HIV-1 enzyme, with a successful approach based on repurposing and optimizing, allowing the identification of potent HBV RNase $\mathrm{H}$ inhibitors that showed promising results in animal models.

The most potent RNase $\mathrm{H}$ inhibitors identified for both HIV-1 and HBV are active site chelating molecules containing a ring with fixed angles, that proved to be the best option to achieve inhibition of the enzymatic function. This approach, in fact, ensures a rigid structural conformation that allows to retain the chelating moiety in a conformation optimal to coordinate the cations of the active site. So far, the most potent HIV-1 RNase $\mathrm{H}$ inhibitor is the HPD derivative 13j (Fig. 10) that showed an $\mathrm{IC}_{50}$ value of $5 \mathrm{nM}$ in enzymatic assays (Wang et al., 2018 c), but inhibited viral replication with an $\mathrm{EC}_{50}$ of only $7.7 \mu \mathrm{M}$, without having any toxicity at concentrations as high as $100 \mu \mathrm{M}$.

On the other hand, the most potent HBV RNase $\mathrm{H}$ inhibitor identified so far is compound A23 (Fig. 16), an $N$-hydroxypyridinedione derivative, active in the nanomolar range against viral replication, with a very high therapeutic index, although absorption-distribution-metabolism-excretion (ADME) properties of these compounds and their stability should be improved before going into further progress in their development.

The reasons behind the slow progress in the anti-HIV-1 RNase $\mathrm{H}$ field are probably related to several factors. First, when compounds are reported to have a high potency in biochemical assays, such as in the low nanomolar range, in most cases there is not a correspondent potency in inhibiting viral replication, raising some concerns about the reliability of the enzymatic assay. To optimize the outcome, the assay should, for example, use conditions that reflect better the physiological ones (Himmel et al., 2014). Second, in the case of active site inhibitors, most of the currently identified compounds often exhibit, together with increased potency, higher toxicity, probably related to inhibition of host counterparts (e.g. human RNases $\mathrm{H1}$ and H2), whose activity is essential for host cell viability (Cerritelli et al., 2003). This selectivity issue should be taken into account in the very preliminary stage of development of new inhibitors, together with the more obvious chemical stability ADME profile, to move further into preclinical investigation.

Often the optimization of pharmacokinetic characteristics can play a crucial role in the progress of molecules through different stages of development, and in this respect HIV-1 and HBV are two worlds apart. The two viral infections are characterized by striking differences that should be taken in to account. HBV infection, localized in the liver, could take advantage of the most advanced techniques of liver-targeting drug delivery (Kang et al., 2016) to enhance the efficacy of the identified lead compounds, reducing systemic distribution and related higher toxicity. The same approach cannot be applied to HIV-1 infection, that requires a systemic treatment that needs to hit cells spread in the host body, even in the compartments most difficult to reach, such as the central nervous system. Even if some attempts with CD4 specific targeting haven been made, they are further more difficult and less effective than liver targeting approaches, and mainly consist of promising monoclonal antibodies to prevent viral attachment (Beccari et al., 2019).

In perspective, a good possibility to optimize HIV-1 RNase $\mathrm{H}$ inhibitors came from the structural information currently available on the HIV-1 RT and on the off-target related proteins, that would allow to design inhibitors whose the metal chelation ability could be flanked by functional groups targeting highly conserved amino acid RT residues that might give selectivity to the viral RNase $\mathrm{H}$. The same approach could be applied to the allosteric inhibitors that, despite being less potent in the enzymatic assays, reached the same potency of inhibition of viral replication, and will have less off-target related toxicity. Structural data envision the presence of a druggable pocket, close to conserved regions, that should be worth of further exploration.

In the case of $\mathrm{HBV}$, RNase $\mathrm{H}$ active site inhibitors are the only 
chemical class investigated. Related to this issue, the lack of structural information suggests that a more classical ligand-based approach should be applied to better delineate the pharmacophore requirements needed for optimization.

A last promising approach envision the possibility to design dualacting compounds. Indeed, as presented in this review, most of the RNase $\mathrm{H}$ inhibitors exhibited collateral activity against other viral-encoded enzymatic functions. This fact, that could represent an issue in the effort to develop selective inhibitors, could be turned into an advantage, by potentially reducing the number of compounds to be administered to HIV positive patients and, also, could provide a higher barrier to the selection of drug resistant strains. Therefore, dual RT and dual RT/IN inhibitors are highly attractive for drug development. Hence, both active site and allosteric inhibitors deserve further development in the next few years.

Finally, from a pure speculative point of view, given the promising data on HBV RNase $\mathrm{H}$ inhibitors, the development of compounds able to block the two viruses at once seems also a really appealing possibility to treat HIV-1/HBV coinfections.

\section{Acknowledgements}

We thank past and present members of our labs and collaborators elsewhere for their contribution to RNase inhibition studies over the years. Work in Madrid was supported in part by grants of the Spanish Ministry of Science, Innovation and Universities (BIO2016-76716-R), and an institutional grant from the Fundación Ramón Areces. A.C. and E.T. were supported by the Sardinian Regional Government grant LR07/17 (F76C18000800002).

\section{References}

Alvarez, M., Matamoros, T., Menéndez-Arias, L., 2009. Increased thermostability and fidelity of DNA synthesis of wild-type and mutant HIV-1 group O reverse transcriptases. J. Mol. Biol. 392, 872-884. https://doi.org/10.1016/j.jmb.2009.07.081.

Amon, J.D., Koshland, D., 2016. RNase H enables efficient repair of R-loop induced DNA damage. Elife 5, e20533. https://doi.org/10.7554/eLife.20533.

Andréola, M.L., Tharaud, D., Litvak, S., Tarrago-Litvak, L., 1993. The ribonuclease H activity of HIV-1 reverse transcriptase: further biochemical characterization and search of inhibitors. Biochimie 75, 127-134.

Beccari, M.V., Mogle, B.T., Sidman, E.F., Mastro, K.A., Asiago-Reddy, E., Kufel, W.D., 2019. Ibalizumab, a novel monoclonal antibody for the management of multidrugresistant HIV-1 infection. Antimicrob. Agents Chemother. 63 e00110-19. https://doi. org/10.1128/AAC.00110-19.

Beilhartz, G.L., Ngure, M., Johns, B.A., DeAnda, F., Gerondelis, P., Götte, M., 2014. Inhibition of the ribonuclease H activity of HIV-1 reverse transcriptase by GSK5750 correlates with slow enzyme-inhibitor dissociation. J. Biol. Chem. 289, 16270-16277. https://doi.org/10.1074/jbc.M114.569707.

Betancor, G., Álvarez, M., Marcelli, B., Andrés, C., Martínez, M.A., Menéndez-Arias, L., 2015. Effects of HIV-1 reverse transcriptase connection subdomain mutations on polypurine tract removal and initiation of $(+)$-strand DNA synthesis. Nucleic Acids Res. 43, 2259-2270. https://doi.org/10.1093/nar/gkv077.

Billamboz, M., Bailly, F., Lion, C., Touati, N., Vezin, H., Calmels, C., Andréola, M.L., Christ, F., Debyser, Z., Cotelle, P., 2011. Magnesium chelating 2-hydroxyisoquinoline-1,3(2H,4H)-diones, as inhibitors of HIV-1 integrase and/or the HIV-1 reverse transcriptase ribonuclease $\mathrm{H}$ domain: discovery of a novel selective inhibitor of the ribonuclease H function. J. Med. Chem. 54, 1812-1824. https://doi.org/10.1021/ jm 1014692.

Borkow, G., Fletcher, R.S., Barnard, J., Arion, D., Motakis, D., Dmitrienko, G.I., Parniak, M.A., 1997. Inhibition of the ribonuclease H and DNA polymerase activities of HIV-1 reverse transcriptase by $\mathrm{N}$-(4-tert-butylbenzoyl)-2-hydroxy-1-naphthaldehyde hydrazone. Biochemistry 36, 3179-3185.

Boyer, P.L., Smith, S.J., Zhao, X.Z., Das, K., Gruber, K., Arnold, E., Burke Jr., T.R., Hughes, S.H., 2018. Developing and evaluating inhibitors against the RNase H active site of HIV-1 reverse transcriptase. J. Virol. 92 e02203-17. https://doi.org/10.1128/jvi. 02203-17.

Budihas, S.R., Gorshkova, I., Gaidamakov, S., Wamiru, A., Bona, M.K., Parniak, M.A., Crouch, R.J., McMahon, J.B., Beutler, J.A., Le Grice, S.F., 2005. Selective inhibition of HIV-1 reverse transcriptase-associated ribonuclease $\mathrm{H}$ activity by hydroxylated tropolones. Nucleic Acids Res. 33, 1249-1256.

Cai, C.W., Lomonosova, E., Moran, E.A., Cheng, X., Patel, K.B., Bailly, F., Cotelle, P., Meyers, M.J., Tavis, J.E., 2014. Hepatitis B virus replication is blocked by a 2-hydroxyisoquinoline-1,3(2H,4H)-dione (HID) inhibitor of the viral ribonuclease $\mathrm{H}$ activity. Antivir. Res. 108, 48-55. https://doi.org/10.1016/j.antiviral.2014.05.007.

Carcelli, M., Rogolino, D., Bacchi, A., Rispoli, G., Fisicaro, E., Compari, C., Sechi, M., Stevaert, A., Naesens, L., 2014. Metal-chelating 2-hydroxyphenyl amide pharmacophore for inhibition of influenza virus endonuclease. Mol. Pharm. 11, 304-316. https://doi.org/10.1021/mp400482a.

Carcelli, M., Rogolino, D., Gatti, A., De Luca, L., Sechi, M., Kumar, G., White, S.W., Stevaert, A., Naesens, L., 2016. N-acylhydrazone inhibitors of influenza virus PA endonuclease with versatile metal binding modes. Sci. Rep. 6, 31500. https://doi. org/10.1038/srep31500.

Carcelli, M., Rogolino, D., Gatti, A., Pala, N., Corona, A., Caredda, A., Tramontano, E., Pannecouque, C., Naesens, L., Esposito, F., 2017. Chelation motifs affecting metaldependent viral enzymes: N'-acylhydrazone ligands as dual target inhibitors of HIV-1 integrase and reverse transcriptase ribonuclease H domain. Front. Microbiol. 8, 440. https://doi.org/10.3389/fmicb.2017.00440.

Cerritelli, S.M., Frolova, E.G., Feng, C., Grinberg, A., Love, P.E., Crouch, R.J., 2003. Failure to produce mitochondrial DNA results in embryonic lethality in Rnaseh1 null mice. Mol. Cell 11, 807-815.

Chang, L.J., Hirsch, R.C., Ganem, D., Varmus, H.E., 1990. Effects of insertional and point mutations on the functions of the duck hepatitis B virus polymerase. J. Virol. 64, 5553-5558.

Chang, M.S., Nguyen, M.H., 2017. Epidemiology of hepatitis B and the role of vaccination. Best Pract. Res. Clin. Gastroenterol. 31, 239-247. https://doi.org/10.1016/j. bpg.2017.05.008.

Chen, Y., Marion, P.L., 1996. Amino acids essential for RNase H activity of hepadnaviruses are also required for efficient elongation of minus-strand viral DNA. J. Virol. 70, 6151-6156.

Chen, Y., Yang, C.J., Wu, Y., Conlon, P., Kim, Y., Lin, H., Tan, W., 2008. Light-switching excimer beacon assays for ribonuclease H kinetic study. Chembiochem 9, 355-359. https://doi.org/10.1002/cbic.200700542.

Chon, H., Matsumura, H., Koga, Y., Takano, K., Kanaya, S., 2006. Crystal structure and structure-based mutational analyses of RNase HIII from Bacillus stearothermophilus: a new type 2 RNase $\mathrm{H}$ with TBP-like substrate-binding domain at the $\mathrm{N}$ terminus. J. Mol. Biol. 356, 165-178.

Christen, M.T., Menon, L., Myshakina, N.S., Ahn, J., Parniak, M.A., Ishima, R., 2012. Structural basis of the allosteric inhibitor interaction on the HIV-1 reverse transcriptase RNase H domain. Chem. Biol. Drug Des. 80, 706-716. https://doi.org/10. 1111/cbdd.12010.

Chung, S., Himmel, D.M., Jiang, J.-K., Wojtak, K., Bauman, J.D., Rausch, J.W., Wilson, J.A., Beutler, J.A., Thomas, C.J., Arnold, E., Le Grice, S.F.J., 2011. Synthesis, activity, and structural analysis of novel $\alpha$-hydroxytropolone inhibitors of human immunodeficiency virus reverse transcriptase-associated ribonuclease H. J. Med. Chem. 54, 4462-4473. https://doi.org/10.1021/jm2000757.

Chung, S., Wendeler, M., Rausch, J.W., Beilhartz, G., Gotte, M., O’Keefe, B.R., Bermingham, A., Beutler, J.A., Liu, S., Zhuang, X., Le Grice, S.F.J., 2010. Structureactivity analysis of vinylogous urea inhibitors of human immunodeficiency virusencoded ribonuclease H. Antimicrob. Agents Chemother. 54, 3913-3921. https://doi org/10.1128/AAC.00434-10.

Chung, S., Miller, J.T., Lapkouski, M., Tian, L., Yang, W., Le Grice, S.F., 2013. Examining the role of the HIV-1 reverse transcriptase p51 subunit in positioning and hydrolysis of RNA/DNA hybrids. J. Biol. Chem. 288, 16177-16184. https://doi.org/10.1074/ jbc.M113.465641.

Corona, A., Desantis, J., Massari, S., Distinto, S., Masaoka, T., Sabatini, S., Esposito, F., Manfroni, G., Maccioni, E., Cecchetti, V., Pannecouque, C., Le Grice, S.F.J., Tramontano, E., Tabarrini, O., 2016a. Studies on cycloheptathiophene-3-carboxamide derivatives as allosteric HIV-1 ribonuclease $\mathrm{H}$ inhibitors. ChemMedChem 11, 1709-1720. https://doi.org/10.1002/cmdc.201600015.

Corona, A., Di Leva, F.S., Thierry, S., Pescatori, L., Cuzzucoli Crucitti, G., Subra, F., Delelis, O., Esposito, F., Rigogliuso, G., Costi, R., Cosconati, S., Novellino, E., Di Santo, R., Tramontano, E., 2014a. Identification of highly conserved residues involved in inhibition of HIV-1 RNase $\mathrm{H}$ function by diketo acid derivatives. Antimicrob. Agents Chemother. 58, 6101-6110. https://doi.org/10.1128/AAC. 03605-14.

Corona, A., Meleddu, R., Esposito, F., Distinto, S., Bianco, G., Masaoka, T., Maccioni, E., Menéndez-Arias, L., Alcaro, S., Le Grice, S.F., Tramontano, E., 2016b. Ribonuclease H/DNA polymerase HIV-1 reverse transcriptase dual inhibitor: mechanistic studies on the allosteric mode of action of isatin-based compound RMNC6. PLoS One 11, e0147225. https://doi.org/10.1371/journal.pone.0147225.

Corona, A., Onnis, V., Deplano, A., Bianco, G., Demurtas, M., Distinto, S., Cheng, Y.-C., Alcaro, S., Esposito, F., Tramontano, E., 2017. Design, synthesis and antiviral evaluation of novel heteroarylcarbothioamide derivatives as dual inhibitors of HIV-1 reverse transcriptase-associated RNase H and RDDP functions. Pathog. Dis. 75, ftx078. https://doi.org/10.1093/femspd/ftx078.

Corona, A., Schneider, A., Schweimer, K., Rösch, P., Wöhrl, B.M., Tramontano, E., 2014b. Inhibition of foamy virus reverse transcriptase by human immunodeficiency virus type 1 RNase H inhibitors. Antimicrob. Agents Chemother. 58, 4086-4093. https:// doi.org/10.1128/AAC.00056-14.

Costi, R., Métifiot, M., Chung, S., Cuzzucoli Crucitti, G., Maddali, K., Pescatori, L., Messore, A., Madia, V.N., Pupo, G., Scipione, L., Tortorella, S., Di Leva, F.S., Cosconati, S., Marinelli, L., Novellino, E., Le Grice, S.F., Corona, A., Pommier, Y., Marchand, C., Di Santo, R., 2014. Basic quinolinonyl diketo acid derivatives as in hibitors of HIV integrase and their activity against RNase $\mathrm{H}$ function of reverse transcriptase. J. Med. Chem. 57, 3223-3234. https://doi.org/10.1021/jm5001503.

Costi, R., Métifiot, M., Esposito, F., Cuzzucoli Crucitti, G., Pescatori, L., Messore, A. Scipione, L., Tortorella, S., Zinzula, L., Novellino, E., Pommier, Y., Tramontano, E., Marchand, C., Di Santo, R., 2013. 6-(-Benzyl-1H-pyrrol-2-yl)-2, 4-dioxo-5-hexenoic acids as dual inhibitors of recombinant HIV-1 integrase and ribonuclease $\mathrm{H}$, synthesized by a parallel synthesis approach. J. Med. Chem. 56, 8588-8598. https://doi. org/10.1021/jm401040b.

Coté, M.L., Roth, M.J., 2008. Murine leukemia virus reverse transcriptase: structural 
comparison with HIV-1 reverse transcriptase. Virus Res. 134, 186-202. https://doi. org/10.1016/j.virusres.2008.01.001.

Cuzzucoli Crucitti, G., Métifiot, M., Pescatori, L., Messore, A., Madia, V.N., Pupo, G., Saccoliti, F., Scipione, L., Tortorella, S., Esposito, F., Corona, A., Cadeddu, M., Marchand, C., Pommier, Y., Tramontano, E., Costi, R., Di Santo, R., 2015. Structureactivity relationship of pyrrolyl diketo acid derivatives as dual inhibitors of HIV-1 integrase and reverse transcriptase ribonuclease $\mathrm{H}$ domain. J. Med. Chem. 58, 1915-1928. https://doi.org/10.1021/jm501799k.

Desideri, N., Sestili, I., Stein, M.L., Tramontano, E., Corrias, S., La Colla, P., 1998. Synthesis and anti-human immunodeficiency virus type 1 integrase activity of hydroxybenzoic and hydroxycinnamic acid flavon-3-yl esters. Antivir. Chem. Chemother. 9, 497-509. https://doi.org/10.1177/095632029800900606.

DeStefano, J.J., Buiser, R.G., Mallaber, L.M., Myers, T.W., Bambara, R.A., Fay, P.J., 1991. Polymerization and RNase $\mathrm{H}$ activities of the reverse transcriptases from avian myeloblastosis, human immunodeficiency, and Moloney murine leukemia viruses are functionally uncoupled. J. Biol. Chem. 266, 7423-7431.

Di Santo, R., 2011. Diketo acids derivatives as dual inhibitors of human immunodeficiency virus type. Curr. Med. Chem. 18, 3335-3342.

Distinto, S., Esposito, F., Kirchmair, J., Cardia, M.C., Gaspari, M., Maccioni, E., Alcaro, S., Markt, P., Wolber, G., Zinzula, L., Tramontano, E., 2012. Identification of HIV-1 reverse transcriptase dual inhibitors by a combined shape-, 2D-fingerprint- and pharmacophore-based virtual screening approach. Eur. J. Med. Chem. 50, 216-229. https://doi.org/10.1016/j.ejmech.2012.01.056.

Distinto, S., Maccioni, E., Meleddu, R., Corona, A., Alcaro, S., Tramontano, E., 2013. Molecular aspects of the RT/drug Interactions. Perspective of dual inhibitors. Curr. Pharmaceut. Des. 19, 1850-1859. https://doi.org/10.2174/1381612811319100009.

Dyda, F., Hickman, A.B., Jenkins, T.M., Engelman, A., Craigie, R., Davies, D.R., 1994 Crystal structure of the catalytic domain of HIV-1 integrase: similarity to other polynucleotidyl transferases. Science 266, 1981-1986.

Edwards, T.C., Lomonosova, E., Patel, J.A., Li, Q., Villa, J.A., Gupta, A.K., Morrison, L.A., Bailly, F., Cotelle, P., Giannakopoulou, E., Zoidis, G., Tavis, J.E., 2017. Inhibition of hepatitis B virus replication by N-hydroxyisoquinolinediones and related polyoxygenated heterocycles. Antivir. Res. 143, 205-217. https://doi.org/10.1016/j. antiviral.2017.04.012.

Edwards, T.C., Mani, N., Dorsey, B., Kakarla, R., Rijnbrand, R., Sofia, M.J., Tavis, J.E., 2019. Inhibition of HBV replication by N-hydroxyisoquinolinedione and N-hydroxypyridinedione ribonuclease $\mathrm{H}$ inhibitors. Antivir. Res. 164, 70-80. https://doi.org/ 10.1016/j.antiviral.2019.02.005.

Esposito, F., Ambrosio, F.A., Maleddu, R., Costa, G., Rocca, R., Maccioni, E., Catalano, R., Romeo, I., Eleftheriou, P., Karia, D.C., Tsirides, P., Godvani, N., Pandya, H., Corona, A., Alcaro, S., Artese, A., Geronikaki, A., Tramontano, E., 2019. Chromenone derivatives as a versatile scaffold with dual mode of inhibition of HIV-1 reverse transcriptase-associated ribonuclease $\mathrm{H}$ function and integrase activity. Eur. J. Med. Chem. 182, 111617. https://doi.org/10.1016/j.ejmech.2019.111617.

Esposito, F., Carli, I., Del Vecchio, C., Xu, L., Corona, A., Grandi, N., Piano, D., Maccioni, E., Distinto, S., Parolin, C., Tramontano, E., 2016. Sennoside A, derived from the traditional Chinese medicine plant Rheum L., is a new dual HIV-1 inhibitor effective on HIV-1 replication. Phytomedicine 23, 1383-1391. https://doi.org/10.1016/j. phymed.2016.08.001.

Esposito, F., Tramontano, E., 2013. Past and future. Current drugs targeting HIV-1 integrase and reverse transcriptase-associated ribonuclease $\mathrm{H}$ activity: single and dual active site inhibitors. Antivir. Chem. Chemother. 23, 129-144. https://doi.org/10. 3851/IMP2690

Evans, D.B., Brawn, K., Deibel Jr., M.R., Tarpley, W.G., Sharma, S.K., 1991. A recombinant ribonuclease $\mathrm{H}$ domain of HIV-1 reverse transcriptase that is enzymatically active. J. Biol. Chem. 266, 20583-20585.

Felts, A.K., Labarge, K., Bauman, J.D., Patel, D.V., Himmel, D.M., Arnold, E., Parniak, M.A., Levy, R.M., 2011. Identification of alternative binding sites for inhibitors of HIV-1 ribonuclease $\mathrm{H}$ through comparative analysis of virtual enrichment studies. J. Chem. Inf. Model. 51 1986-1598. https://doi.org/10.1021/ci200194w.

Figiel, M., Chon, H., Cerritelli, S.M., Cybulska, M., Crouch, R.J., Nowotny, M., 2011. The structural and biochemical characterization of human RNase $\mathrm{H} 2$ complex reveals the molecular basis for substrate recognition and Aicardi-Goutières syndrome defects. J. Biol. Chem. 286, 10540-10550. https://doi.org/10.1074/jbc.M110.181974.

Figiel, M., Nowotny, M., 2014. Crystal structure of RNase H3-substrate complex reveals parallel evolution of RNA/DNA hybrid recognition. Nucleic Acids Res. 42, 9285-9294. https://doi.org/10.1093/nar/gku615.

Fujishita, T., Mikamiyama, M., Kawai, M., Akiyama, T., 2010. Substituted 3-Hydroxy-4Pyridone Derivative. WO2010110231, patent.

Gao, P., Wang, X., Sun, L., Cheng, X., Poongavanam, V., Kongsted, J., Álvarez, M., Luczkowiak, J., Pannecouque, C., De Clercq, E., Lee, K.H., Chen, C.H., Liu, H., Menéndez-Arias, L., Liu, X., Zhan, P., 2019. Design, synthesis, and biologic evaluation of novel galloyl derivatives as HIV-1 RNase H inhibitors. Chem. Biol. Drug Des. 93, 582-589. https://doi.org/10.1111/cbdd.13455.

Gao, P., Zhang, L., Sun, L., Huang, T., Tan, J., Zhang, J., Zhou, Z., Zhao, T., MenéndezArias, L., Pannecouque, C., De Clercq, E., Zhan, P., Liu, X., 2017. 1-Hydroxypyrido [2,3-d]pyrimidin-2(1H)-ones as novel selective HIV integrase inhibitors obtained via privileged substructure-based compound libraries. Bioorg. Med. Chem. 25, 5779-5789. https://doi.org/10.1016/j.bmc.2017.09.006.

Gill, M.S.A., Hassan, S.S., Ahemad, N., 2019. Evolution of HIV-1 reverse transcriptase and integrase dual inhibitors: recent advances and developments. Eur. J. Med. Chem. 179, 423-448. https://doi.org/10.1016/j.ejmech.2019.06.058.

Gong, Q., Menon, L., Ilina, T., Miller, L.G., Ahn, J., Parniak, M.A., Ishima, R., 2011. Interaction of HIV-1 reverse transcriptase ribonuclease $\mathrm{H}$ with an acylhydrazone inhibitor. Chem. Biol. Drug Des. 77, 39-47. https://doi.org/10.1111/j.1747-0285. 2010.01052.x.
Hafkemeyer, P., Neftel, K., Hobi, R., Pfaltz, A., Lutz, H., Lüthi, K., Focher, F., Spadari, S., Hübscher, U., 1991. HP 0.35, a cephalosporin degradation product is a specific inhibitor of lentiviral RNAses H. Nucleic Acids Res. 19, 4059-4065.

Himmel, D.M., Sarafianos, S.G., Dharmasena, S., Hossain, M.M., McCoy-Simandle, K., Ilina, T., Clark Jr., A.D., Knight, J.L., Julias, J.G., Clark, P.K., Krogh-Jespersen, K. Levy, R.M., Hughes, S.H., Parniak, M.A., Arnold, E., 2006. HIV-1 reverse transcriptase structure with RNase $\mathrm{H}$ inhibitor dihydroxy benzoyl naphthyl hydrazone bound at a novel site. ACS Chem. Biol. 1, 702-712.

Himmel, D.M., Maegley, K.A., Pauly, T.A., Bauman, J.D., Das, K., Dharia, C., Clark Jr., A.D., Ryan, K., Hickey, M.J., Love, R.A., Hughes, S.H., Bergqvist, S., Arnold, E., 2009 Structure of HIV-1 reverse transcriptase with the inhibitor $\beta$-thujaplicinol bound at the RNase H active site. Structure 17, 1625-1635. https://doi.org/10.1016/j.str. 2009.09.016.

Himmel, D.M., Myshakina, N.S., Ilina, T., Van Ry, A., Ho, W.C., Parniak, M.A., Arnold, E., 2014. Structure of a dihydroxycoumarin active-site inhibitor in complex with the RNase H domain of HIV-1 reverse transcriptase and structure-activity analysis of inhibitor analogs. J. Mol. Biol. 426, 2617-2631. https://doi.org/10.1016/j.jmb. 2014.05.006.

Hu, Y., Cheng, X., Cao, F., Huang, A., Tavis, J.E., 2013. ß-Thujaplicinol inhibits hepatitis B virus replication by blocking the viral ribonuclease $\mathrm{H}$ activity. Antivir. Res. 99, 221-229.

Hu, J., Seeger, C., 2015. Hepadnavirus genome replication and persistence. Cold Spring Harb. Perspect. Med. 5, a021386. https://doi.org/10.1101/cshperspect.a021386.

Huang, H., Chopra, R., Verdine, G.L., Harrison, S.C., 1998. Structure of a covalently trapped catalytic complex of HIV-1 reverse transcriptase: implications for drug resistance. Science 282, 1669-1675.

Huber, A.D., Michailidis, E., Tang, J., Puray-Chavez, M.N., Boftsi, M., Wolf, J.J., Boschert, K.N., Sheridan, M.A., Leslie, M.D., Kirby, K.A., Singh, K., Mitsuya, H., Parniak, M.A., Wang, Z., Sarafianos, S.G., 2017. 3-Hydroxypyrimidine-2,4-diones as novel hepatitis $B$ virus antivirals targeting the viral ribonuclease. H. Antimicrob. Agents Chemother. 61 e00245-17. https://doi.org/10.1128/AAC.00245-17.

Hughes, S.H., 2015. Reverse transcription of retroviruses and LTR retrotransposons. Microbiol. Spectr. 3 MDNA3-0027-2014.

Hyjek, M., Figiel, M., Nowotny, M., 2019. RNases H: structure and mechanism. DNA Repair (Amst), pp. 102672 (in press).

Jeong, H.S., Backlund, P.S., Chen, H.C., Karavanov, A.A., Crouch, R.J., 2004. RNase H2 of Saccharomyces cerevisiae is a complex of three proteins. Nucleic Acids Res. 32, 407-414.

Jiang, F., Chen, W., Yi, K., Wu, Z., Si, Y., Han, W., Zhao, Y., 2010. The evaluation of catechins that contain a galloyl moiety as potential HIV-1 integrase inhibitors. Clin. Immunol. 137, 347-356. https://doi.org/10.1016/j.clim.2010.08.007.

Johns, B.A., Kawasuji, T., Weatherhead, J.G., Taishi, T., Temelkoff, D.P., Yoshida, H., Akiyama, T., Taoda, Y., Murai, H., Kiyama, R., Fuji, M., Tanimoto, N., Jeffrey, J., Foster, S.A., Yoshinaga, T., Seki, T., Kobayashi, M., Sato, A., Johnson, M.N., Garvey, E.P., Fujiwara, T., 2013. Carbamoyl pyridone HIV-1 integrase inhibitors 3. A diastereomeric approach to chiral nonracemic tricyclic ring systems and the discovery of dolutegravir (S/GSK1349572) and (S/GSK1265744). J. Med. Chem. 56, 5901-5916. https://doi.org/10.1021/jm400645w.

Jones, S.A., Boregowda, R., Spratt, T.E., Hu, J., 2012. In vitro RNA-dependent protein priming activity of human hepatitis B virus polymerase. J. Virol. 86, 5134-5150 Erratum in: J. Virol. 87, 2013, 12504.

Kang, J.H., Toita, R., Murata, M., 2016. Liver cell-targeted delivery of therapeutic molecules. Crit. Rev. Biotechnol. 36, 132-143. https://doi.org/10.3109/07388551. 2014.930017.

Kankanala, J., Kirby, K.A., Huber, A.D., Casey, M.C., Wilson, D.J., Sarafianos, S.G., Wang, Z., 2017. Design, synthesis and biological evaluations of N-hydroxy thienopyrimidine-2,4-diones as inhibitors of HIV reverse transcriptase-associated RNase H. Eur. J. Med. Chem. 141, 149-161. https://doi.org/10.1016/j.ejmech.2017.09.054.

Kankanala, J., Kirby, K.A., Liu, F., Miller, L., Nagy, E., Wilson, D.J., Parniak, M.A., Sarafianos, S.G., Wang, Z., 2016. Design, synthesis, and biological evaluations of hydroxypyridonecarboxylic acids as inhibitors of HIV reverse transcriptase associated RNase H. J. Med. Chem. 59, 5051-5062. https://doi.org/10.1021/acs.jmedchem. $6 \mathrm{~b} 00465$.

Karwan, R., Wintersberger, U., 1986. Yeast ribonuclease H(70) cleaves RNA-DNA junctions. FEBS Lett. 206, 189-192. https://doi.org/10.1016/0014-5793(86)80978-4.

Katayanagi, K., Miyagawa, M., Matsushima, M., Ishikawa, M., Kanaya, S., Ikehara, M. Matsuzaki, T., Morikawa, K., 1990. Three-dimensional structure of ribonuclease $\mathrm{H}$ from E. coli. Nature 347, 306-309.

Kati, W.M., Johnson, K.A., Jerva, L.F., Anderson, K.S., 1992. Mechanism and fidelity of HIV reverse transcriptase. J. Biol. Chem. 267, 25988-25997.

Kharlamova, T., Esposito, F., Zinzula, L., Floris, G., Cheng, Y.-C., Dutschman, G., Tramontano, E., 2009. Inhibition of HIV-1 ribonuclease $\mathrm{H}$ activity by novel frangulaemodine derivatives. Med. Chem. 5, 398-410. https://doi.org/10.2174/ 157340609789117840 .

Khudyakov, Y.E., Makhov, A.M., 1989. Prediction of terminal protein and ribonuclease H domains in the gene P product of hepadnaviruses. FEBS Lett. 243, 115-118.

Kirby, K.A., Myshakina, N.A., Christen, M.T., Chen, Y.L., Schmidt, H.A., Huber, A.D., Xi, Z., Kim, S., Rao, R.K., Kramer, S.T., Yang, Q., Singh, K., Parniak, M.A., Wang, Z., Ishima, R., Sarafianos, S.G., 2017. A 2-hydroxyisoquinoline-1,3-dione active-site RNase $\mathrm{H}$ inhibitor binds in multiple modes to HIV-1 reverse transcriptase. Antimicrob. Agents Chemother. 61 e01351-17. https://doi.org/10.1128/AAC. 01351-17.

Kirschberg, T.A., Balakrishnan, M., Squires, N.H., Barnes, T., Brendza, K.M., Chen, X., Eisenberg, E.J., Jin, W., Kutty, N., Leavitt, S., Liclican, A., Liu, Q., Liu, X., Mak, J., Perry, J.K., Wang, M., Watkins, W.J., Lansdon, E.B., 2009. RNase H active site inhibitors of human immunodeficiency virus type 1 reverse transcriptase: design, 
biochemical activity, and structural information. J. Med. Chem. 52, 5781-5784. https://doi.org/10.1021/jm900597q.

Klumpp, K., 2003. Two-metal ion mechanism of RNA cleavage by HIV RNase H and mechanism-based design of selective HIV RNase H inhibitors. Nucleic Acids Res. 31, 6852-6859. https://doi.org/10.1093/nar/gkg881.

Klumpp, K., Hang, J.Q., Rajendran, S., Yang, Y., Derosier, A., Wong Kai In, P., Overton, H., Parkes, K.E., Cammack, N., Martin, J.A., 2003. Two-metal ion mechanism of RNA cleavage by HIV RNase $\mathrm{H}$ and mechanism-based design of selective HIV RNase H inhibitors. Nucleic Acids Res. 31, 6852-6859. https://doi.org/10.1093/nar/gkg881.

Kogoma, T., Foster, P.L., 1998. In: Ribonucleases, H., Crouch, R.J., Toulme, J.J. (Eds.), Physiological Functions of E. coli RNase HI. INSERM, Paris, France, pp. 39-66.

Krupovic, M., Blomberg, J., Coffin, J.M., Dasgupta, I., Fan, H., Geering, A.D., Gifford, R., Harrach, B., Hull, R., Johnson, W., Kreuze, J.F., Lindemann, D., Llorens, C., Lockhart, B., Mayer, J., Muller, E., Olszewski, N.E., Pappu, H.R., Pooggin, M.M., RichertPöggeler, K.R., Sabanadzovic, S., Sanfaçon, H., Schoelz, J.E., Seal, S., Stavolone, L., Stoye, J.P., Teycheney, P.Y., Tristem, M., Koonin, E.V., Kuhn, J.H., 2018. Ortervirales: new virus order unifying five families of reverse-transcribing viruses. J. Virol. 92 e00515-18. https://doi.org/10.1128/JVI.00515-18.

Lanford, R.E., Notvall, L., Lee, H., Beames, B., 1997. Transcomplementation of nucleotide priming and reverse transcription between independently expressed TP and RT domains of the hepatitis B virus reverse transcriptase. J. Virol. 71, 2996-3004.

Lansdon, E.B., Liu, Q., Leavitt, S.A., Balakrishnan, M., Perry, J.K., Lancaster-Moyer, C., Kutty, N., Liu, X., Squires, N.H., Watkins, W.J., Kirschberg, T.A., 2011. Structural and binding analysis of pyrimidinol carboxylic acid and N-hydroxy quinazolinedione HIV1 RNase H inhibitors. Antimicrob. Agents Chemother. 55 2905-1915. https://doi. org/10.1128/AAC.01594-10.

Levrero, M., Subic, M., Villeret, F., Zoulim, F., 2018. Perspectives and limitations for nucleo(t)side analogs in future HBV therapies. Curr. Opin. Virol. 30, 80-89. https:// doi.org/10.1016/j.coviro.2018.04.006.

Li, A., Li, J., Johnson, K.A., 2016. HIV-1 reverse transcriptase polymerase and RNase H (ribonuclease $\mathrm{H}$ ) active sites work simultaneously and independently. J. Biol. Chem. 291, 26566-26585.

Li, F., Li, P., Yang, L., Tang, B., 2012. Simple and sensitive fluorescence detection of the RNA endonuclease activity of mammalian argonaute 2 protein based on an RNA molecular beacon. Chem. Commun. 48, 12192-12194. https://doi.org/10.1039/ c2cc36404b.

Li, Y., Xuan, S., Feng, Y., Yan, A., 2015. Targeting HIV-1 integrase with strand transfer inhibitors. Drug Discov. Today 20, 435-449. https://doi.org/10.1016/j.drudis.2014. 12.001

Lima, W.F., Murray, H.M., Damle, S.S., Hart, C.E., Hung, G., De Hoyos, C.L., Liang, X.H., Crooke, S.T., 2016. Viable RNaseH1 knockout mice show RNaseH1 is essential for R loop processing, mitochondrial and liver function. Nucleic Acids Res. 44, 5299-5312. https://doi.org/10.1093/nar/gkw350.

Liu, B., Xiang, D., Long, Y., Tong, C., 2013. Real time monitoring of junction ribonuclease activity of RNase H using chimeric molecular beacons. Analyst 138, 3238-3245. https://doi.org/10.1039/c3an36414c.

Lomonosova, E., Daw, J., Garimallaprabhakaran, A.K., Agyemang, N.B., Ashani, Y., Murelli, R.P., Tavis, J.E., 2017. Efficacy and cytotoxicity in cell culture of novel $\alpha$ hydroxytropolone inhibitors of hepatitis B virus ribonuclease. H. Antiviral Res. 144, 164-172. https://doi.org/10.1016/j.antiviral.2017.06.014.

Lomonosova, E., Tavis, J.E., 2017. In vitro enzymatic and cell culture-based assays for measuring activity of HBV RNase H inhibitors. Methods Mol. Biol. 1540, 179-192.

Long, K.R., Lomonosova, E., Li, Q., Ponzar, N.L., Villa, J.A., Touchette, E., Rapp, S., Liley, R.M., Murelli, R.P., Grigoryan, A., Buller, R.M., Wilson, L., Bial, J., Sagartz, J.E. Tavis, J.E., 2018. Efficacy of hepatitis B virus ribonuclease H inhibitors, a new class of replication antagonists, in FRG human liver chimeric mice. Antivir. Res. 149, 41-47.

Loya, S., Hizi, A., 1993. The interaction of illimaquinone, a selective inhibitor of the RNase $\mathrm{H}$ activity, with the reverse transcriptases of human immunodeficiency and murine leukemia retroviruses. J. Biol. Chem. 268, 9323-9328.

Loya, S., Tal, R., Kashman, Y., Hizi, A., 1990. Illimaquinone, a selective inhibitor of the RNase $\mathrm{H}$ activity of human immunodeficiency virus type 1 reverse transcriptase. Antimicrob. Agents Chemother. 34, 2009-2012.

Lu, G., Lomonosova, E., Cheng, X., Moran, E.A., Meyers, M.J., Le Grice, S.F., Thomas, C.J., Jiang, J.K., Meck, C., Hirsch, D.R., D’Erasmo, M.P., Suyabatmaz, D.M., Murelli, R.P., Tavis, J.E., 2015. Hydroxylated tropolones inhibit hepatitis B virus replication by blocking the viral ribonuclease $\mathrm{H}$ activity. Antimicrob. Agents Chemother. 59, 1070-1079.

MacLachlan, J.H., Cowie, B.C., 2015. Hepatitis B virus epidemiology. Cold Spring Harb. Perspect. Med. 5, a021410. https://doi.org/10.1101/cshperspect.a021410.

Majorek, K.A., Dunin-Horkawicz, S., Steczkiewicz, K., Muszewska, A., Nowotny, M., Ginalski, K., Bujnicki, J.M., 2014. The RNase H-like superfamily: new members, comparative structural analysis and evolutionary classification. Nucleic Acids Res. 42, 4160-4179. https://doi.org/10.1093/nar/gkt1414.

Martini, R., Esposito, F., Corona, A., Ferrarese, R., Ceresola, E.R., Visconti, L., Tintori, C., Barbieri, A., Calcaterra, A., Iovine, V., Canducci, F., Tramontano, E., Botta, M., 2017. Natural product kuwanon-L inhibits HIV-1 replication through multiple target binding. Chembiochem 18, 374-377. https://doi.org/10.1002/cbic.201600592.

Masaoka, T., Chung, S., Caboni, P., Rausch, J.W., Wilson, J.A., Taskent-Sezgin, H., Beutler, J., Tocco, G., Le Grice, S.F.J., 2013. Exploiting drug-resistant enzymes as tools to identify thienopyrimidinone inhibitors of human immunodeficiency virus reverse transcriptase-associated ribonuclease H. J. Med. Chem. 56, 5436-5445. https://doi.org/10.1021/jm400405z.

Massari, S., Corona, A., Distinto, S., Desantis, J., Caredda, A., Sabatini, S., Manfroni, G., Felicetti, T., Cecchetti, V., Pannecouque, C., Maccioni, E., Tramontano, E., Tabarrini, O., 2019. From cycloheptathiophene-3-carboxamide to oxazinone-based derivatives as allosteric HIV-1 ribonuclease H inhibitors. J. Enzym. Inhib. Med. Chem. 34, 55-74. https://doi.org/10.1080/14756366.2018.1523901.

Meleddu, R., Cannas, V., Distinto, S., Sarais, G., Del Vecchio, C., Esposito, F., Bianco, G., Corona, A., Cottiglia, F., Alcaro, S., Parolin, C., Artese, A., Scalise, D., Fresta, M., Arridu, A., Ortuso, F., Maccioni, E., Tramontano, E., 2014. Design, synthesis, and biological evaluation of 1,3-diarylpropenones as dual inhibitors of HIV-1 reverse transcriptase. ChemMedChem 9, 1869-1879. https://doi.org/10.1002/cmdc. 201402015.

Meleddu, R., Distinto, S., Corona, A., Bianco, G., Cannas, V., Esposito, F., Artese, A., Alcaro, S., Matyus, P., Bogdan, D., Cottiglia, F., Tramontano, E., Maccioni, E., 2015. (3Z)-3-(2-[4-(aryl)-1,3-thiazol-2-yl]hydrazin-1-ylidene)-2,3-dihydro- $1 \mathrm{H}$-indol-2-one derivatives as dual inhibitors of HIV-1 reverse transcriptase. Eur. J. Med. Chem. 93, 452-460. https://doi.org/10.1016/j.ejmech.2015.02.032.

Meleddu, R., Distinto, S., Corona, A., Tramontano, E., Bianco, G., Melis, C., Cottiglia, F. Maccioni, E., 2017. Isatin thiazoline hybrids as dual inhibitors of HIV-1 reverse transcriptase. J. Enzym. Inhib. Med. Chem. 32, 130-136. https://doi.org/10.1080/ 14756366.2016.1238366.

Menéndez-Arias, L., 2013. Molecular basis of human immunodeficiency virus type 1 drug resistance: overview and recent developments. Antivir. Res. 98, 93-120. https://doi. org/10.1016/j.antiviral.2013.01.007.

Menéndez-Arias, L., Abraha, A., Quiñones-Mateu, M.E., Mas, A., Camarasa, M.-J., Arts, E.J., 2001. Functional characterization of chimeric reverse transcriptases with polypeptide subunits of highly divergent HIV-1 group M and O strains. J. Biol. Chem. 276, 27470-27479.

Menéndez-Arias, L., Álvarez, M., Pacheco, B., 2014. Nucleoside/nucleotide analog inhibitors of hepatitis B virus polymerase: mechanism of action and resistance. Curr. Opin. Virol. 8, 1-9. https://doi.org/10.1016/j.coviro.2014.04.005.

Menéndez-Arias, L., Sebastián-Martín, A., Álvarez, M., 2017. Viral reverse transcriptases. Virus Res. 234, 153-176. https://doi.org/10.1016/j.virusres.2016.12.019.

Moelling, K., Broecker, F., Russo, G., Sunagawa, S., 2017. RNase H as gene modifier, driver of evolution and antiviral defense. Front. Microbiol. 8, 1745. https://doi.org/ 10.3389/fmicb.2017.01745.

Mölling, K., Bolognesi, D.P., Bauer, H., Büsen, W., Plassmann, H.W., Hausen, P., 1971. Association of viral reverse transcriptase with an enzyme degrading the RNA moiety of RNA-DNA hybrids. Nat. New Biol. 234, 240-243. https://doi.org/10.1038/ newbio234240a0.

Nassal, M., 2008. Hepatitis B viruses: reverse transcription a different way. Virus Res. 134, 235-249. https://doi.org/10.1016/j.virusres.2007.12.024.

Nowak, E., Potrzebowski, W., Konarev, P.V., Rausch, J.W., Bona, M.K., Svergun, D.I. Bujnicki, J.M., Le Grice, S.F., Nowotny, M., 2013. Structural analysis of monomeric retroviral reverse transcriptase in complex with an RNA/DNA hybrid. Nucleic Acids Res. 41, 3874-3887.

Nowotny, M., 2009. Retroviral integrase superfamily: the structural perspective. EMBO Rep. 10, 144-151. https://doi.org/10.1038/embor.2008.256.

Nowotny, M., Yang, W., 2006. Stepwise analyses of metal ions in RNase H catalysis from substrate destabilization to product release. EMBO J. 25, 1924-1933.

Nowotny, M., Gaidamakov, S.A., Ghirlando, R., Cerritelli, S.M., Crouch, R.J., Yang, W., 2007. Structure of human RNase H1 complexed with an RNA/DNA hybrid: insight into HIV reverse transcription. Mol. Cell 28, 264-276 Erratum in: Mol Cell. 2007, 28 513.

Ohtani, N., Haruki, M., Morikawa, M., Crouch, R.J., Itaya, M., Kanaya, S., 1999. Identification of the genes encoding Mn2+-dependent RNase HII and Mg2 +-dependent RNase HIII from Bacillus subtilis: classification of RNases $\mathrm{H}$ into three families. Biochemistry 38, 605-618.

Pala, N., Esposito, F., Rogolino, D., Carcelli, M., Sanna, V., Palomba, M., Naesens, L., Corona, A., Grandi, N., Tramontano, E., Sechi, M., 2016. Inhibitory effect of 2,3,5,6 tetrafluoro-4-[4-(aryl)-1H-1,2,3-triazol-1-yl]benzenesulfonamide derivatives on HIV reverse transcriptase associated RNase H activities. Int. J. Mol. Sci. 17, e1371. https://doi.org/10.3390/ijms17081371.

Parniak, M.A., Min, K.L., Budihas, S.R., Le Grice, S.F., Beutler, J.A., 2003. A fluorescencebased high-throughput screening assay for inhibitors of human immunodeficiency virus- 1 reverse transcriptase-associated ribonuclease $\mathrm{H}$ activity. Anal. Biochem. 322, 33-39.

Pei, Y., Wang, C., Yan, S.F., Liu, G., 2017. Past, current, and future developments of therapeutic agents for treatment of chronic hepatitis B virus infection. J. Med. Chem. 60, 6461-6479. Erratum in: J. Med. Chem. 60, 6766-6767. https://doi.org/10.1021/ acs.jmedchem.6b01442.

Quiñones-Mateu, M.E., Soriano, V., Domingo, E., Menéndez-Arias, L., 1997. Characterization of the reverse transcriptase of a human immunodeficiency virus type 1 group O isolate. Virology 236, 364-373.

Rice, P.A., Baker, T.A., 2001. Comparative architecture of transposase and integrase complexes. Nat. Struct. Biol. 8, 302-307.

Rosta, E., Yang, W., Hummer, G., 2014. Calcium inhibition of ribonuclease H1 two-metal ion catalysis. J. Am. Chem. Soc. 136, 3137-3144. https://doi.org/10.1021/ ja411408x.

Sanna, C., Rigano, D., Corona, A., Piano, D., Formisano, C., Farci, D., Franzini, G., Ballero, M., Chianese, G., Tramontano, E., Taglialatela-Scafati, O., Esposito, F., 2018a. Dual HIV-1 reverse transcriptase and integrase inhibitors from Limonium morisianum Arrigoni, an endemic species of Sardinia (Italy). Nat. Prod. Res. 33, 1798-1803. https://doi.org/10.1080/14786419.2018.1434649.

Sanna, C., Scognamiglio, M., Fiorentino, A., Corona, A., Graziani, V., Caredda, A., Cortis, P., Montisci, M., Ceresola, E.R., Canducci, F., Poli, F., Tramontano, E., Esposito, F., 2018b. Prenylated phloroglucinols from Hypericum scruglii, an endemic species of Sardinia (Italy), as new dual HIV-1 inhibitors effective on HIV-1 replication. PLoS One 13, e0195168. https://doi.org/10.1371/journal.pone.0195168.

Schneider, A., Corona, A., Spöring, I., Jordan, M., Buchholz, B., Maccioni, E., Di Santo, R., Bodem, J., Tramontano, E., Wöhrl, B.M., 2016. Biochemical characterization of a 
multi-drug resistant HIV-1 subtype AG reverse transcriptase: antagonism of AZT discrimination and excision pathways and sensitivity to RNase $\mathrm{H}$ inhibitors. Nucleic Acids Res. 44, 2310-2322. https://doi.org/10.1093/nar/gkw060.

Schödel, F., Weimer, T., Will, H., Sprengel, R., 1988. Amino acid sequence similarity between retroviral and E. coli RNase $\mathrm{H}$ and hepadnaviral gene products. AIDS Res. Hum. Retrovir. 4, ix-xi.

Schultz, S.J., Champoux, J.J., 2008. RNase H activity: structure, specificity, and function in reverse transcription. Virus Res. 134, 86-103. https://doi.org/10.1016/j.virusres. 2007.12.007.

Semenova, E.A., Johnson, A.A., Marchand, C., Davis, D.A., Yarchoan, R., Pommier, Y., 2006. Preferential inhibition of the magnesium-dependent strand transfer reaction of HIV-1 integrase by $\alpha$-hydroxytropolones. Mol. Pharmacol. 69, 1454-1460.

Seto, W.K., Lo, Y.R., Pawlotsky, J.M., Yuen, M.F., 2018. Chronic hepatitis B virus infection. Lancet 392, 2313-2324. https://doi.org/10.1016/S0140-6736(18)31865-8.

Shaw-Reid, C.A., Munshi, V., Graham, P., Wolfe, A., Witmer, M., Danzeisen, R., Olsen, D.B., Carroll, S.S., Embrey, M., Wai, J.S., Miller, M.D., Cole, J.L., Hazuda, D.J., 2003. Inhibition of HIV-1 ribonuclease $\mathrm{H}$ by a novel diketo acid, 4-[5-(benzoylamino)thien2-yl]-2,4-dioxobutanoic acid. J. Biol. Chem. 278, 2777-2780.

Singh, K.P., Crane, M., Audsley, J., Avihingsanon, A., Sasadeusz, J., Lewin, S.R., 2017. HIV-hepatitis B virus coinfection: epidemiology, pathogenesis, and treatment. AIDS 31, 2035-2052. https://doi.org/10.1097/QAD.0000000000001574.

Sluis-Cremer, N., Arion, D., Abram, M.E., Parniak, M., 2004. Proteolytic processing of an HIV-1 pol polyprotein precursor: insights into the mechanism of reverse transcriptase p66/p51 heterodimer formation. Int. J. Biochem. Cell Biol. 36, 1836-1847. https:// doi.org/10.1016/j.biocel.2004.02.020.

Sluis-Cremer, N., Arion, D., Parniak, M.A., 2002. Destabilization of the HIV-1 reverse transcriptase dimer upon interaction with $\mathrm{N}$-acyl hydrazone inhibitors. Mol. Pharmacol. 62, 398-405.

Sonar, V.P., Corona, A., Distinto, S., Maccioni, E., Meleddu, R., Fois, B., Floris, C., Malpure, N.V., Alcaro, S., Tramontano, E., Cottiglia, F., 2017. Natural product-inspired esters and amides of ferulic and caffeic acid as dual inhibitors of HIV-1 reverse transcriptase. Eur. J. Med. Chem. 130, 248-260. https://doi.org/10.1016/j.ejmech. 2017.02.054.

Stein, H., Hausen, P., 1969. Enzyme from calf thymus degrading the RNA moiety of DNARNA hybrids: effect on DNA-dependent RNA polymerase. Science 166, 393-395. https://doi.org/10.1126/science.166.3903.393.

Steitz, T.A., Steitz, J.A., 1993. A general two-metal-ion mechanism for catalytic RNA. Proc. Natl. Acad. Sci. U.S.A. 90, 6498-6502.

Su, H.P., Yan, Y., Prasad, G.S., Smith, R.F., Daniels, C.L., Abeywickrema, P.D., Reid, J.C., Loughran, H.M., Kornienko, M., Sharma, S., Grobler, J.A., Xu, B., Sardana, V., Allison, T.J., Williams, P.D., Darke, P.L., Hazuda, D.J., Munshi, S., 2010. Structural basis for the inhibition of RNase $\mathrm{H}$ activity of HIV-1 reverse transcriptase by RNase $\mathrm{H}$ active site-directed inhibitors. J. Virol. 84, 7625-7633. https://doi.org/10.1128/JVI 00353-10.

Summa, V., Petrocchi, A., Matassa, V.G., Taliani, M., Laufer, R., De Francesco, R., Altamura, S., Pace, P., 2004. HCV NS5b RNA-dependent RNA polymerase inhibitors: from $\alpha, \gamma$ - diketoacids to 4,5-dihydroxypyrimidine- or 3-methyl-5-hydroxypyrimidinonecarboxylic acids. Design and synthesis. J. Med. Chem. 47, 5336-5339. https://doi.org/10.1021/jm0494669.

Sun, L., Gao, P., Dong, G., Zhang, X., Cheng, X., Ding, X., Wang, X., Daelemans, D., De Clercq, E., Pannecouque, C., Menéndez-Arias, L., Zhan, P., Liu, X., 2018. 5Hydroxypyrido[2,3-b]pyrazin-6(5H)-one derivatives as novel dual inhibitors of HIV1 reverse transcriptase-associated ribonuclease $\mathrm{H}$ and integrase. Eur. J. Med. Chem. 155, 714-724. https://doi.org/10.1016/j.ejmech.2018.06.036.

Tadokoro, T., Kanaya, S., 2009. Ribonuclease H: molecular diversities, substrate binding domains, and catalytic mechanism of the prokaryotic enzymes. FEBS J. 276, 1482-1493. https://doi.org/10.1111/j.1742-4658.2009.06907.x.

Tang, J., Do, H.T., Huber, A.D., Casey, M.C., Kirby, K.A., Wilson, D.J., Kankanala, J. Parniak, M.A., Sarafianos, S.G., Wang, Z., 2019. Pharmacophore-based design of novel 3-hydroxypyrimidine-2,4-dione subtypes as inhibitors of HIV reverse transcriptase-associated RNase H: tolerance of a nonflexible linker. Eur. J. Med. Chem. 166, 390-399. https://doi.org/10.1016/j.ejmech.2019.01.081.

Tang, J., Kirby, K.A., Huber, A.D., Casey, M.C., Ji, J., Wilson, D.J., Sarafianos, S.G., Wang, Z., 2017b. 6-Cyclohexylmethyl-3-hydroxypyrimidine-2,4-dione as an inhibitor scaffold of HIV reverase transcriptase: impacts of the 3-OH on inhibiting RNase $\mathrm{H}$ and polymerase. Eur. J. Med. Chem. 128, 168-179. https://doi.org/10.1016/j.ejmech. 2017.01.041.

Tang, J., Liu, F., Nagy, E., Miller, L., Kirby, K.A., Wilson, D.J., Wu, B., Sarafianos, S.G., Parniak, M.A., Wang, Z., 2016. 3-Hydroxypyrimidine-2,4-diones as selective active site inhibitors of HIV reverse transcriptase-associated RNase H: design, synthesis, and biochemical evaluations. J. Med. Chem. 59, 2648-2659. https://doi.org/10.1021/ acs.jmedchem.5b01879.

Tang, J., Maddali, K., Dreis, C.D., Sham, Y.Y., Vince, R., Pommier, Y., Wang, Z., 2011. N-3 hydroxylation of pyrimidine-2,4-diones yields dual inhibitors of HIV reverse transcriptase and integrase. ACS Med. Chem. Lett. 2, 63-67. https://doi.org/10.1021/ ml1002162.

Tang, J., Vernekar, S.K.V., Chen, Y.L., Miller, L., Huber, A.D., Myshakina, N., Sarafianos, S.G., Parniak, M.A., Wang, Z., 2017a. Synthesis, biological evaluation and molecular modeling of 2-hydroxyisoquinoline-1,3-dione analogues as inhibitors of HIV reverse transcriptase associated ribonuclease $\mathrm{H}$ and polymerase. Eur. J. Med. Chem. 133, 85-96. https://doi.org/10.1016/j.ejmech.2017.03.059.

Tavis, J.E., Cheng, X., Hu, Y., Totten, M., Cao, F., Michailidis, E., Aurora, R., Meyers, M.J., Jacobsen, E.J., Parniak, M.A., Sarafianos, S.G., 2013. The hepatitis B virus ribonuclease $\mathrm{H}$ is sensitive to inhibitors of the human immunodeficiency virus ribonuclease
$\mathrm{H}$ and integrase enzymes. PLoS Pathog. 9, e1003125.

Tavis, J.E., Zoidis, G., Meyers, M.J., Murelli, R.P., 2019. Chemical approaches to inhibiting the hepatitis B virus ribonuclease H. ACS Infect. Dis. 5, 655-658. https://doi. org/10.1021/acsinfecdis.8b00045.

Tomassini, J., Selnick, H., Davies, M.E., Armstrong, M.E., Baldwin, J., Bourgeois, M., Hastings, J., Hazuda, D., Lewis, J., McClements, W., 1994. Inhibition of cap (m7GpppXm)-dependent endonuclease of influenza virus by 4-substituted 2,4-dioxobutanoic acid compounds. Antimicrob. Agents Chemother. 38, 2827-2837.

Tramontano, E., 2006. HIV-1 RNase H: recent progress in an exciting, yet little explored, drug target. Mini Rev. Med. Chem. 6, 727-737. https://doi.org/10.2174/ 138955706777435733.

Tramontano, E., Di Santo, R., 2010. HIV-1 RT-associated RNase H function inhibitors: recent advances in drug development. Curr. Med. Chem. 17, 2837-2853. https://doi. org/10.2174/092986710792065045.

Tramontano, E., Esposito, F., Badas, R., Di Santo, R., Costi, R., La Colla, P., 2005. 6-[1-(4Fluorophenyl)methyl-1H-pyrrol-2-yl)]-2,4-dioxo-5-hexenoic acid ethyl ester a novel diketo acid derivative which selectively inhibits the HIV-1 viral replication in cell culture and the ribonuclease $\mathrm{H}$ activity in vitro. Antivir. Res. 65, 117-124. https:// doi.org/10.1016/j.antiviral.2004.11.002.

Velthuisen, E.J., Johns, B.A., Gerondelis, P., Chen, Y., Li, M., Mou, K., Zhang, W., Seal, J.W., Hightower, K.E., Miranda, S.R., Brown, K., Leesnitzer, L., 2014 Pyridopyrimidinone inhibitors of HIV-1 RNase H. Eur. J. Med. Chem. 83, 609-616. https://doi.org/10.1016/j.ejmech.2014.06.061.

Vernekar, S.K.V., Liu, Z., Nagy, E., Miller, L., Kirby, K.A., Wilson, D.J., Kankanala, J., Sarafianos, S.G., Parniak, M.A., Wang, Z., 2015. Design, synthesis, biochemical, and antiviral evaluations of C6 benzyl and C6 biarylmethyl substituted 2-hydroxylisoquinoline-1,3-diones: dual inhibition against HIV reverse transcriptase-associated RNase $\mathrm{H}$ and polymerase with antiviral activities. J. Med. Chem. 58, 651-664. https://doi.org/10.1021/jm501132s.

Villa, J.A., Pike, D.P., Patel, K.B., Lomonosova, E., Lu, G., Abdulqader, R., Tavis, J.E. 2016. Purification and enzymatic characterization of the hepatitis B virus ribonuclease H: a new target for antiviral inhibitors. Antivir. Res. 132, 186-195.

Vörös, J., Urbanek, A., Rautureau, G.J., O'Connor, M., Fisher, H.C., Ashcroft, A.E., Ferguson, N., 2014. Large-scale production and structural and biophysical characterizations of the human hepatitis B virus polymerase. J. Virol. 88, 2584-2599.

Wai, J.S., Egbertson, M.S., Payne, L.S., Fisher, T.E., Embrey, M.W., Tran, L.O., Melamed, J.Y., Langford, H.M., Guare, J.P., Zhuang, L., Grey, V.E., Vacca, J.P., Holloway, M.K., Naylor-Olsen, A.M., Hazuda, D.J., Felock, P.J., Wolfe, A.L., Stillmock, K.A., Schleif, W.A., Gabryelski, L.J., Young, S.D., 2000. 4-Aryl-2,4-dioxobutanoic acid inhibitors of HIV-1 integrase and viral replication in cells. J. Med. Chem. 43, 4923-4926. https:// doi.org/10.1021/jm000176b.

Wang, X., Gao, P., Menéndez-Arias, L., Liu, X., Zhan, P., 2018a. Update on recent developments in small molecular HIV-1 RNase H inhibitors (2013-2016): opportunities and challenges. Curr. Med. Chem. 25, 1682-1702. https://doi.org/10.2174/ 0929867324666170113110839.

Wang, L., Tang, J., Huber, A.D., Casey, M.C., Kirby, K.A., Wilson, D.J., Kankanala, J., Parniak, M.A., Sarafianos, S.G., Wang, Z., 2018b. 6-Biphenylmethyl-3-hydroxypyrimidine-2,4-diones potently and selectively inhibited HIV reverse transcriptaseassociated RNase H. Eur. J. Med. Chem. 156, 680-691. https://doi.org/10.1016/j. ejmech.2018.07.035.

Wang, L., Tang, J., Huber, A.D., Casey, M.C., Kirby, K.A., Wilson, D.J., Kankanala, J., Xie, J., Parniak, M.A., Sarafianos, S.G., Wang, Z., 2018c. 6-Arylthio-3-hydroxypyrimidine2,4-diones potently inhibited HIV reverse transcriptase-associated RNase $\mathrm{H}$ with antiviral activity. Eur. J. Med. Chem. 156, 652-665. https://doi.org/10.1016/j. ejmech.2018.07.039.

Wendeler, M., Lee, H.-F., Bermingham, A., Miller, J.T., Chertov, O., Bona, M.K., Baichoo, N.S., Ehteshami, M., Beutler, J., O’Keefe, B.R., Götte, M., Kvaratskhelia, M., Le Grice, S., 2008. Vinylogous ureas as a novel class of inhibitors of reverse transcriptase-associated ribonuclease H activity. ACS Chem. Biol. 3, 635-644. https://doi.org/10. 1021/cb8001039.

Williams, P.D., Staas, D.D., Venkatraman, S., Loughran, H.M., Ruzek, R.D., Booth, T.M., Lyle, T.A., Wai, J.S., Vacca, J.P., Feuston, B.P., Ecto, L.T., Flynn, J.A., DiStefano, D.J., Hazuda, D.J., Bahnck, C.M., Himmelberger, A.L., Dornadula, G., Hrin, R.C., Stillmock, K.A., Witmer, M.V., Miller, M.D., Grobler, J.A., 2010. Potent and selective HIV-1 ribonuclease $\mathrm{H}$ inhibitors based on a 1-hydroxy-1,8-naphthyridin-2(1H)-one scaffold. Bioorg. Med. Chem. Lett 20, 6754-6757. https://doi.org/10.1016/j.bmcl. 2010.08.135.

World Health Organization, 2017. Global Hepatitis Report 2017. World Health Organization, Geneva, pp. 83.

Wu, B., Tang, J., Wilson, D.J., Huber, A.D., Casey, M.C., Ji, J., Kankanala, J., Xie, J., Sarafianos, S.G., Wang, Z., 2016. 3-Hydroxypyrimidine-2,4-dione-5-N-benzylcarboxamides potently inhibit HIV-1 integrase and RNase H. J. Med. Chem. 59, 6136-6148. https://doi.org/10.1021/acs.jmedchem.6b00040.

Wu, H., Lima, W.F., Crooke, S.T., 1998. Molecular cloning and expression of cDNA for human RNase H. Antisense Nucleic Acid Drug Dev 8, 53-61.

Yang, W., Hendrickson, W.A., Crouch, R.J., Satow, Y., 1990. Structure of ribonuclease H phased at $2 \mathrm{~A}$ resolution by MAD analysis of the selenomethionyl protein. Science 249, 1398-1405.

Yang, W., Lee, J.Y., Nowotny, M., 2006. Making and breaking nucleic acids: two-Mg2+ ion catalysis and substrate specificity. Mol. Cell 22, 5-13.

You, D.J., Chon, H., Koga, Y., Takano, K., Kanaya, S., 2007. Crystal structure of type 1 ribonuclease $\mathrm{H}$ from hyperthermophilic archaeon Sulfolobus tokodaii: role of argi nine 118 and C-terminal anchoring. Biochemistry 46, 11494-11503. 